\title{
Towards a more effective and reliable salt crystallization test for porous building materials: state of the art
}

\author{
Barbara Lubelli - Veerle Cnudde - Teresa Diaz-Goncalves • Elisa Franzoni • \\ Rob P. J. van Hees - Ioannis Ioannou - Beatriz Menendez • Cristiana Nunes • \\ Heiner Siedel • Maria Stefanidou • Veronique Verges-Belmin • \\ Heather Viles
}

Received: 11 January 2018/Accepted: 21 March 2018/Published online: 5 April 2018

(C) The Author(s) 2018

\begin{abstract}
The durability of building materials with respect to salt crystallization is commonly determined by accelerated weathering tests, carried out in the laboratory. An effective laboratory weathering test should assess the durability and, in the case of conservation of historic buildings, the compatibility of repair materials with those existing. Besides, the test should provide reliable results within a reasonable period of time, accelerating the deterioration process without however altering its mechanism. Despite several national and international standards, recommendations and guidelines, a commonly accepted
\end{abstract}

This report was prepared by the working group within RILEM TC 271-ASC, and further reviewed and approved by all members of the RILEM TC 271-ASC.

TC Membership:

TC Chairman: Barbara Lubelli.

TC Secretary: Inge Rörig-Dalgaard.

TC Members: Kévin Beck, Christine Bläuer, Veerle Cnudde, Stefano De Miranda, Hannelore Derluyn, Teresa Diaz Goncalves, Robert J. Flatt, Elisa Franzoni, Ioannis Ioannou, Barbara Lubelli, Beatriz Menendez, Cristiana Nunes, Inge Rörig-Dalgaard, Noushine Shahidzadeh, Heiner Siedel, Zuzana Slizkova, Maria Stefanidou, Rob van Hees, Rosario Veiga, Véronique Verges-Belmin, Heather Viles.

B. Lubelli $(\varangle) \cdot$ R. P. J. van Hees

Faculty of Architecture, Delft University of Technology,

Delft, The Netherlands

e-mail: b.lubelli@tudelft.nl testing protocol does not yet exist. Researchers often develop and apply their own procedure, a fact that complicates comparison between different studies. The RILEM Technical Committee 271 ASC has been set up with the scope of developing improved test procedures for the assessment of the behaviour of materials under the influence of salt crystallization, which should overcome the limitations of existing standards and recommendations. This paper constitutes one of the first results of the work of the Technical Committee. It critically reviews the literature on salt crystallization tests, identifies advantages and limitations of the several test protocols and

V. Cnudde

Department of Geology, Ghent University, Ghent, Belgium

T. Diaz-Goncalves

Laboratorio Nacional de Engenharia Civil (LNEC),

Lisbon, Portugal

\section{E. Franzoni}

Department of Civil, Chemical, Environmental and Materials Engineering (DICAM), University of Bologna, Bologna, Italy

R. P. J. van Hees

TNO, Delft, The Netherlands
I. Ioannou
Department of Civil and Environmental Engineering,
University of Cyprus, Nicosia, Cyprus 
provides new ideas for the development of improved salt crystallization procedures.

Keywords Literature review - Salt damage $\cdot$ Salt crystallization test $\cdot$ Porous materials $\cdot$ RILEM

\section{Introduction}

Salt crystallization is a major cause of damage in porous building materials (e.g. [1-3]). Despite extensive ongoing research in this field, the complexity of the problem has hindered the use of theoretical models for forecasting decay due to salt crystallization. Indeed, in the practice of construction and conservation, the durability of materials with respect to salt crystallization, when not well-known from past field experience, is generally determined by accelerated weathering laboratory tests.

An effective laboratory weathering test should assess the durability of a material and, in the case of conservation of historic buildings, the compatibility of repair materials with pre-existing ones. Besides, the test should provide reliable results within a reasonable period of time, accelerating the deterioration process without altering its mechanism.

Despite the availability of a European standard (EN 12370) [4], three RILEM recommendations (RILEM 1980 [5], MS-A.1 [6], MS-A.2 [7]) and other

B. Menendez

Department of GeoSciences and Environmental Sciences, Université de Cergy-Pontoise, Cergy-Pontoise, France

C. Nunes

Institute of Theoretical and Applied Mechanics of the Czech Academy of Sciences, Prague, Czech Republic

\section{H. Siedel}

Institute of Geotechnical Engineering, Dresden University of Technology, Dresden, Germany

\section{Stefanidou}

School of Civil Engineering, Aristotle University of Thessaloniki, Thessaloníki, Greece

\section{Verges-Belmin}

Laboratoire de Recherche des Monuments Historiques (LRMH), Champs-sur-Marne, France

H. Viles

School of Geography and the Environment, University of Oxford, Oxford, UK guidelines (e.g. [8]), a commonly accepted testing protocol does not yet exist. In fact, there is a reluctance among researchers to use standard tests, a fact which hinders comparison between the results of different studies. This reluctance is probably motivated by some important limitations of the above mentioned standards and recommendations. For example, the European standard EN 12370 prescribes very aggressive weathering conditions (cycles of immersion in highly concentrated sodium sulphate solution followed by drying at $\left.105^{\circ} \mathrm{C}\right)[9,10]$. This may result in damage patterns that are different from those known from practice for the material concerned (Fig. 1). RILEM MS-A.1 [6] proposes the use of more realistic test conditions, i.e. contamination by capillary absorption
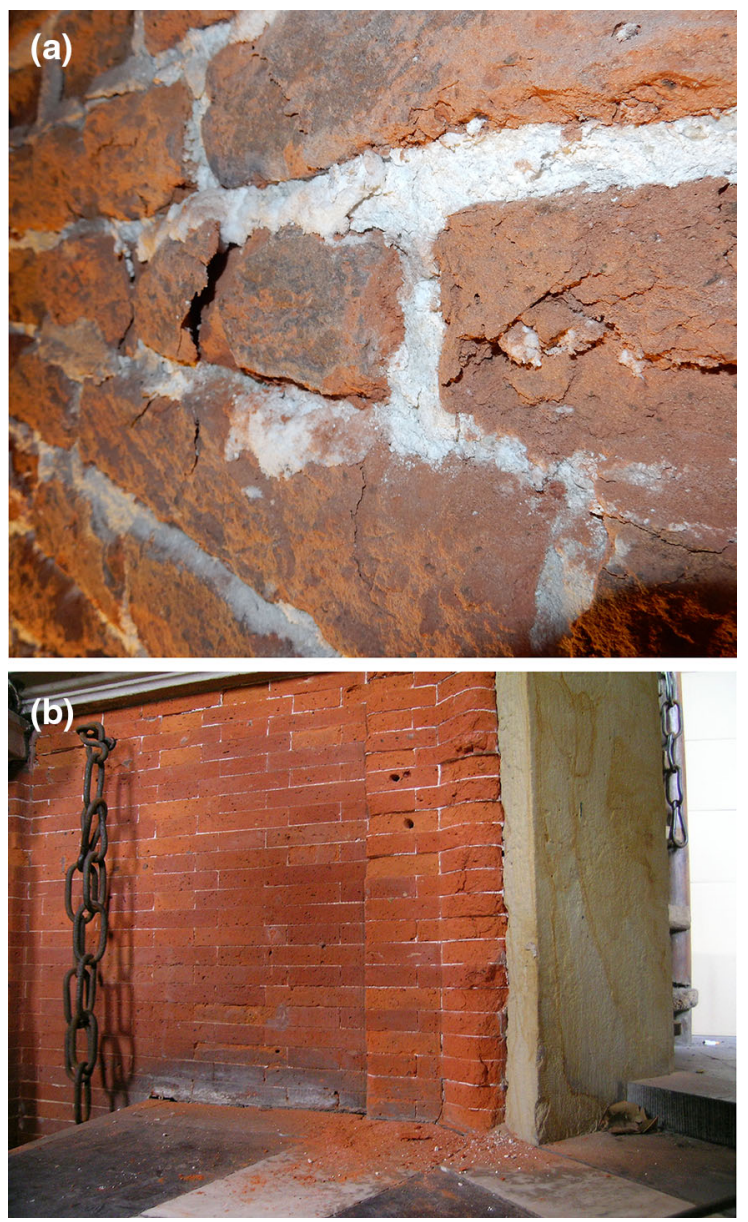

Fig. 1 Decay due to salt crystallization. a Brick exfoliation and spalling due to sodium sulphate crystallization (Westertoren, Amsterdam, the Netherlands). b Powdering of brick due to sodium chloride crystallization (Waag building, Amsterdam, the Netherlands) 
of $10 \mathrm{wt} \%$ sodium sulphate or sodium chloride solution followed by drying at $20{ }^{\circ} \mathrm{C}$ and $50 \%$ relative humidity $(\mathrm{RH})$, but still has the important limitation of being very time consuming.

Moreover, none of the existing standards prescribes an accurate, reliable and quantitative method or technique for monitoring damage development during the test. Another limitation of current standards consists in the scarce validation of the results from the accelerated test through comparison with field data, e.g. in terms of damage type and severity [11].

The RILEM Technical Committee 271-ASC (Accelerated laboratory test for the assessment of the durability of materials with respect to salt crystallization), initiated in 2016, aims at overcoming the above-mentioned limitations by the development of improved test procedures for the assessment of the behaviour of building materials with respect to salt crystallization.

The present paper is a first step towards this objective. It reviews the literature on the subject with the aim of:

- Providing an overview of existing standards and other test procedures;

- Identifying advantages and limitations of different test procedures;

- Providing input for the development of improved test procedures.

This review, as well as the to-be-developed test, focuses on the simulation of salt damage triggered by capillary transport of salt solution and evaporation at the surface, which is the situation most often observed in practice. Test procedures simulating sea-salt spray will not be considered, as standard tests in this field are quite well-accepted.

This paper is structured in five sections, each focusing on one of the crucial variables defining a salt crystallization test procedure:

- Specimen type, shape, size and number of replicates;

- Salt type and amount;

- Salt contamination procedure;

- Drying conditions;

- Methods for the assessment of damage and criteria for the evaluation of decay.

Based on the review, ideas are provided for the development of effective salt crystallization procedures.

\section{Specimen}

\subsection{Single material or combination}

Most standards and guidelines prescribe the use of single material specimens (EN 12370, WTA 2005, RILEM 1980, RILEM MS-A.1 1998) [4-8]. Similarly, much of the experimental research reported in the literature has been carried out on single materials. However, although testing single materials may resemble practice in the case of objects like statues, in general, different materials are assembled in structures and the interaction between them can affect the durability of each material and of the whole structure.

To the authors' best knowledge, the first recommendation to propose the use of specimens comprising a combination of materials is MS-A.2 "Uni-directional salt crystallization test for masonry units" (RILEM TC 127-MS,1998) [7]. Later on, the use of multi-material specimens became more common in laboratory tests. While assemblages of different natural stones are rarely tested [12], combinations of materials are quite often used when assessing the durability of bedding and pointing mortars or plasters (e.g. [13-19]) (Fig. 2a). In fact, testing mortars or plasters as single materials could result in misleading or incomplete results, as the behaviour of these materials is strongly affected by the adjacent ones. Furthermore, cracking and detachment of a plaster layer from its substrate, which is a common decay type in plasters with water repellent properties when applied on salt loaded substrates (Fig. 2b), cannot be simulated when testing the plaster alone. An additional reason to test a mortar in combination with another material is that the latter can absorb water from the fresh mortar and affect the pore structure of the hardened mortar, thus possibly influencing its salt resistance [20,21].

For natural stone, the orientation of the bedding plane is another variable to consider. Smith and MacGreevy [22] and Cnudde et al. [23] showed how this orientation can affect decay type and development.

\subsection{Number, size and shape}

The number of replicate specimens specified in standard crystallization tests is generally larger than what is actually used by researchers. EN 12370 [4] prescribes the use of at least 6 replicates, whilst 
RILEM MS-A.1 [6] suggests 10. However, in the literature, the number of replicates is mostly limited to a maximum of three. In a few cases, more replicates are used, especially when damage is monitored with destructive techniques [23-25].

The size of the test specimens varies considerably: for single materials, EN 12370 [1] prescribes the use of $40 \mathrm{~mm}$ side cubic specimens; RILEM MS-A.2 (for brick units) [7] suggests the use of prismatic specimens (entire brick units) with a maximum length of $120 \mathrm{~mm}$ between the absorption and the test (crystallization) faces. In general, except when small masonry units are used (ca. $200 \times 200 \times 100 \mathrm{~mm}^{3}[6,14]$ ), the specimen size is less than $1 \mathrm{dm}^{3}$. The use of small specimens not only saves material, but it can considerably speed up the test, as it reduces the absorption and drying times $[15,26]$.

The size of the specimen is sometimes chosen based also on the selected assessment method. Cubic or prismatic specimens are most often used in laboratory
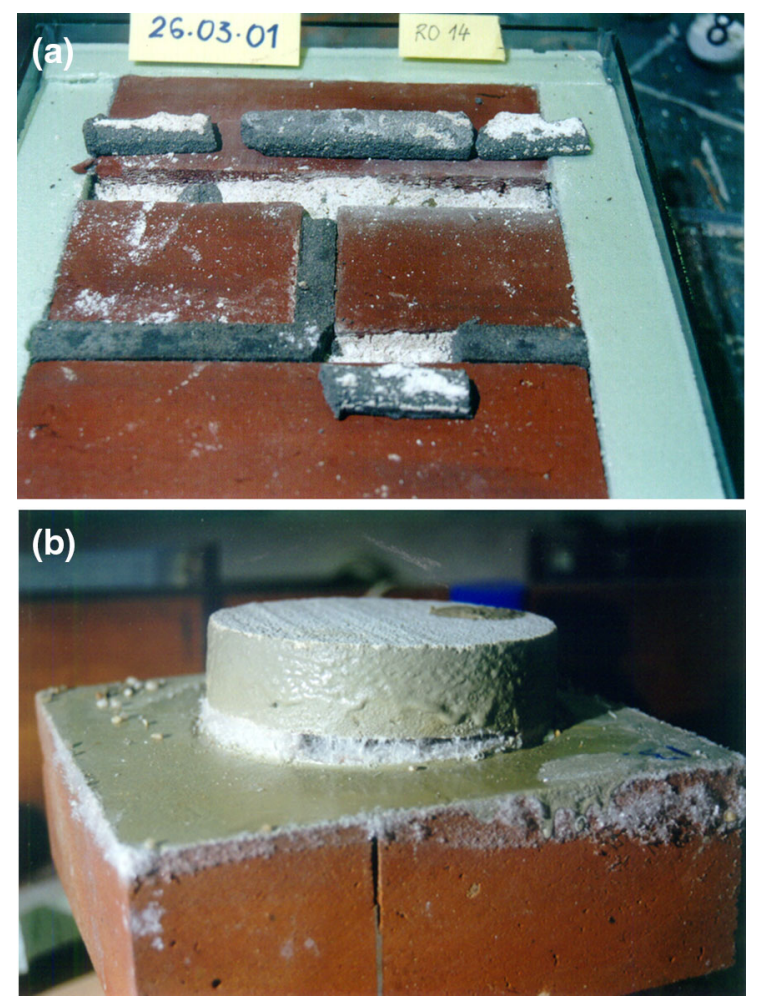

Fig. 2 Commonly observed decay types due to salt crystallization reproduced in the laboratory on specimens made of more than one material: push out of pointing mortar (a) and detachment of a plaster with mixed-in water repellent agent from the substrate (b) tests. Sometimes, cylinders are used; this shape has the advantage of reducing corner effects and stress concentrations [27, 28]. Additionally, when using $\mathrm{X}$-ray CT to monitor the weathering dynamically, cylinders allow the analysis of a larger volume at a specific resolution [23, 29].

The choice of the shape is also affected by other factors, such as the contamination procedure (e.g. elongated specimens are generally used in continuous partial immersion tests) and the assessment method. For example, Nunes et al. [30] used $40 \times 40 \times 160 \mathrm{~mm}^{3}$ mortar prisms to enable measurement of the flexural strength before and after the crystallization test.

In general, the concept of a representative elementary volume (i.e. the smallest volume over which a measurement can be made that will yield a value representative of the material properties and of the length scale over which salt crystallization damage may occur [31, 32]) might be used to define the minimum size of the specimen.

\section{Salts}

\subsection{Single salts}

In laboratory tests, mainly single salts are used; in buildings, however, salt mixtures are commonly found, rather than individual salts.

The most common salt used in laboratory tests is sodium sulfate (Fig. 3), which is often prescribed in standards (e.g. [4]) and recommendations (e.g. [6]). As alternatives, magnesium sulphate [33] or sodium chloride [6] are considered. The main reason for using sodium sulphate is its aggressiveness, which is

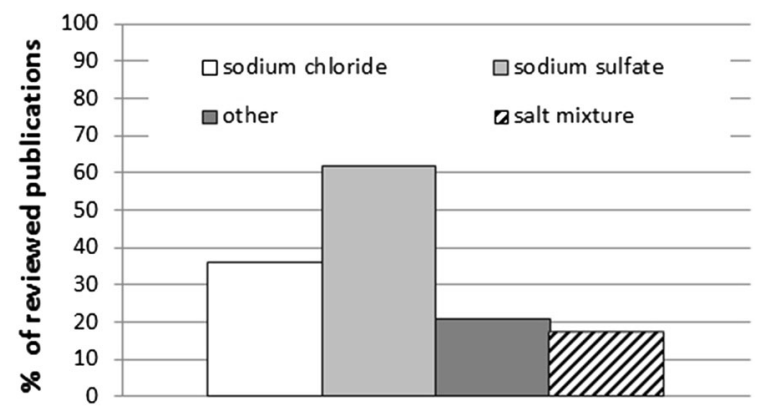

Fig. 3 Salts used in salt crystallization tests (percentage based on 90 publications on salt crystallization tests reviewed in this paper (in some studies more than one salt is considered)) 
attributed to its several hydrated phases with different solubility degrees (e.g. [34-37]) and which has been widely experimentally confirmed by the scientific literature. In 1970, Goudie et al. [38] and Kwaad [39] began extensive experimental research to compare the aggressiveness of different salts $\left(\mathrm{Na}_{2} \mathrm{SO}_{4}, \mathrm{MgSO}_{4}\right.$, $\mathrm{NaCl}, \mathrm{Na}_{2} \mathrm{CO}_{3}, \mathrm{CaCl}_{2}, \mathrm{CaSO}_{4}$ ) in the weathering of natural stone. Both studies showed $\mathrm{Na}_{2} \mathrm{SO}_{4}$ to be the most destructive salt, the most recurrent weathering patterns being splitting in sedimentary rocks and disintegration in granites. The aggressiveness of $\mathrm{Na}_{2} \mathrm{SO}_{4}$ was confirmed by Cooke [40], who used saturated solutions of $\mathrm{Na}_{2} \mathrm{SO}_{4}, \mathrm{CaSO}_{4}, \mathrm{NaCl}$ and $\mathrm{NaNO}_{3}$, as well as a sea salts mixture, to test the durability of sandstones and slate. Sodium sulphate produced extensive disintegration, whereas other salts induced no significant damage during a forty-day test period. Smith and McGreevy [22] performed crystallization tests on sandstones using solutions of $\mathrm{Na}_{2} \mathrm{SO}_{4}$, $\mathrm{MgSO}_{4}$ and $\mathrm{NaCl}$. They found that, under the selected test conditions (spraying of $10 \%$ salt solutions followed by drying at $100{ }^{\circ} \mathrm{C}$ ), $\mathrm{MgSO}_{4}$ and, in some cases, $\mathrm{NaCl}$ can produce more damage than $\mathrm{Na}_{2} \mathrm{SO}_{4}$. Besides, they observed that the type of damage is also affected by the number of cycles: initially, granular disintegration occurred, followed by cracks and flaking during the last cycles.

Like sodium sulphate, magnesium sulphate has multiple hydrated forms with different solubilities, and hence, it can be very aggressive. Several researchers [22, 38, 41-43], compared the aggressiveness of magnesium sulphate to other salts using different laboratory tests and all confirmed that magnesium sulphate can cause severe damage. Ruiz-Agudo et al. [42], underline that sodium and magnesium sulphates lead to different weathering patterns due to differences in solution properties and crystallization behaviour: in the case of $\mathrm{Na}_{2} \mathrm{SO}_{4}$ scale formation was observed in the tested calcarenites, whereas $\mathrm{MgSO}_{4}$ caused crack development throughout the bulk of the stone. These differences are confirmed by Balboni et al. [44] and Espinosa-Marzal and Scherer [45]. Despite its aggressiveness, magnesium sulphate is used much less commonly than sodium sulphate in laboratory studies.

Another salt often used in laboratory tests is $\mathrm{NaCl}$. This salt is generally reported to be much less damaging than $\mathrm{Na}_{2} \mathrm{SO}_{4}$. When comparing the aggressiveness of $\mathrm{NaCl}$ to that of other salts, Goudie et al. [38] found that $\mathrm{NaCl}$ could not produce any damage in immersion tests. Different results were obtained by Kwaad [39], who reported that $\mathrm{NaCl}$ produced some damage in granites, albeit less than that caused by $\mathrm{Na}_{2} \mathrm{SO}_{4}, \mathrm{MgSO}_{4}$ and $\mathrm{Na}_{2} \mathrm{CO}_{3}$. Rodriguez Navarro and Doehne [46] compared the effect of $\mathrm{NaCl}$ and $\mathrm{Na}_{2} \mathrm{SO}_{4}$ on the weathering of oolitic limestone, at two $\mathrm{RH}$ conditions, under continuous capillarity solution supply. Also in these experiments, $\mathrm{NaCl}$ was considered much less aggressive than $\mathrm{Na}_{2} \mathrm{SO}_{4}$, as damage was negligible at any RH. Gentilini et al. [47] studied masonry specimens contaminated with $\mathrm{Na}_{2} \mathrm{SO}_{4}$ and $\mathrm{NaCl}$ solutions at low concentrations. They found that in specimens contaminated with $\mathrm{NaCl}$ efflorescences were spread on the surface, not leading to any significant visible damage, whereas in samples affected by $\mathrm{Na}_{2} \mathrm{SO}_{4}$ efflorescences were concentrated in the mortar joints and edges of the specimens, causing exfoliation and flaking of the brick corners. Stefanidou and Papayanni [48] studied air-lime and pozzolanic mortars contaminated with sodium sulphate and sodium chloride solutions at different concentrations, using the weathering procedure of EN 12370 [4]: they found that sodium sulphate produced severe damage in the form of cracks in the bulk of the mortar, whereas in the case of $\mathrm{NaCl}$ some sanding and scaling of the surface was observed.

The literature shows that there is a striking discrepancy between the limited damage observed in laboratory and the severe decay occurring in the field when materials are contaminated with $\mathrm{NaCl}$ (Fig. 1b). When considering damage due to salt crystallization in pores, the lower destructive potential of $\mathrm{NaCl}$ in laboratory tests has been attributed to its low tendency to supersaturate (e.g. [46, 49]) and high tendency to form efflorescence rather than subflorescence [17, 46]. Some authors focused on the development of a laboratory crystallization test specific for $\mathrm{NaCl}$, able to reproduce more effectively the decay observed in the field. Lubelli [50] developed a test which first enhanced the accumulation of salt just beneath the surface of the material and then subjected the specimen to RH cycles between 0 and $96 \%$ RH. When using this procedure, damage was obtained in $\mathrm{NaCl}$ laden materials in a relatively short time [50]. DiazGoncalves and Delgado-Rodrigues [51] compared the resistance of painted and unpainted plasters to $\mathrm{NaCl}$ and $\mathrm{Na}_{2} \mathrm{SO}_{4}$ crystallization. Dissolution and crystallization cycles were produced both by rewetting with water and drying at variable temperature and RH. In 
these test conditions, $\mathrm{NaCl}$ proved to be more aggressive than $\mathrm{Na}_{2} \mathrm{SO}_{4}$.

Nitrates (mostly $\mathrm{NaNO}_{3}$ ), carbonates (mostly $\mathrm{Na}_{2} \mathrm{CO}_{3}$ ), and other sulphates (mostly gypsum) have occasionally been used. Goudie [52] carried out salt crystallization experiments with different salts using continuous absorption followed by drying at temperatures between 22 and $55{ }^{\circ} \mathrm{C}$. He reports $\mathrm{Na}_{2} \mathrm{CO}_{3}$ to be the most aggressive salt under the studied conditions, followed by $\mathrm{MgSO}_{4}$ and $\mathrm{Na}_{2} \mathrm{SO}_{4}$. In contrast, De Freece et al. [53], in an experiment consisting of crystallization/dissolution induced by $\mathrm{RH}$ changes, found $\mathrm{Na}_{2} \mathrm{CO}_{3}$ to be less aggressive than $\mathrm{Na}_{2} \mathrm{SO}_{4}$ and attributed its lower aggressiveness to its slower rate of response to RH variations. The aforementioned discrepancies are most probably due to the differences between the test procedures used.

\subsection{Salt mixtures}

The use of salt mixtures is less common in salt weathering tests. WTA recommendation [8] prescribes the use of a mixture of $\mathrm{NaCl}, \mathrm{Na}_{2} \mathrm{SO}_{4}$ and $\mathrm{NaNO}_{3}$ for testing the salt resistance of renovation plasters.

Some researchers choose the composition of the brine for salt weathering tests based on the analysis of the salt present in naturally weathered building materials [54] to reproduce as well as possible a specific field condition. Other authors compare the aggressiveness of single salts to that of their mixtures.

The aggressiveness of sea salt mixtures has been compared to that of $\mathrm{NaCl}$ [40] and $\mathrm{Na}_{2} \mathrm{SO}_{4}$ [55]. With only a few exceptions, the decay observed in specimens contaminated with sea salts was slightly more severe than in those laden with $\mathrm{NaCl}$ alone. Williams and Robinson [56] investigated the aggressiveness of salts common in efflorescence on rock outcrops in Central Europe: next to gypsum, potassium alum, ammonium alum, a combined potassium alum and alunogen were tested, both as single salts and as combinations. In these tests alunogen was "ineffective", whereas the three alums were highly destructive; gypsum as a single salt caused minimal weathering, but the addition of gypsum significantly enhanced the damage caused by alums. The same authors [57] also tested $\mathrm{NaCl}$ and combinations of alums with $\mathrm{NaCl}$ and alunogen. They concluded that some combinations of salts can significantly enhance weathering, while other combinations are less damaging; however, no explanation is given for these differences. De Clercq [58, 59] investigated the effect of $\mathrm{NaNO}_{3}, \mathrm{KNO}_{3}$ and $\mathrm{K}_{2} \mathrm{SO}_{4}$ on the crystallization damage caused by sodium sulfate and concluded that the deteriorating effect of $\mathrm{Na}_{2} \mathrm{SO}_{4}$ was diminished due to the formation of double salts. The formation of different types of double salts and their different effects on pore clogging is reported also by Godts et al. [60], who investigated the behaviour of sodium and magnesium sulfate and mixtures of both at different environmental conditions.

Menendez and Petránová [61] performed tests using three different salts $\left(\mathrm{NaCl}, \mathrm{Na}_{2} \mathrm{SO}_{4}\right.$ and $\left.\mathrm{CaSO}_{4}\right)$ and a mixture of them. They concluded that the mixture induced less damage than the single salts, and highlighted the complexity of the possible influencing factors, e.g. alteration of salt accumulation and drying rates, in the case of mixtures.

\section{Salt contamination}

\subsection{Salt contamination procedure}

The most common salt contamination procedures entail the repeated total or partial immersion of specimens in a salt solution, followed by a drying period (wet-dry cycles), or their continuous partial immersion (simultaneous absorption and drying, i.e. the so-called wick effect) (Fig. 4). Generally, in partial immersion tests, contamination with salt solution is provided through the surface opposite to the evaporation surface (test surface). In those cases when total immersion or spraying techniques are used, the contamination and the evaporation surfaces coincide. Arizzi et al. [62] studied the effect of salt deposition (from the test surface) and capillary salt up-take on mortar specimens, and observed that salt capillary uptake produced more damage than salt deposition.

Experiments using full immersion techniques prevail in the literature (often some variant of EN 12370 (e.g. [63]). Some authors (e.g. [64]) argue that, while this is not a common condition in practice, it reduces the dispersion of the results. Full immersion is not considered suitable to test specimens with surface treatments; in this case, contamination (and possibly rewetting) by partial immersion from the side opposite to the treated one (e.g. $[65,66])$ is a better option. 
Fig. 4 Overview of the most common salt contamination procedures: a repeated total immersion of the specimen; $\mathbf{b}$ repeated partial immersion; c continuous partial immersion (a)

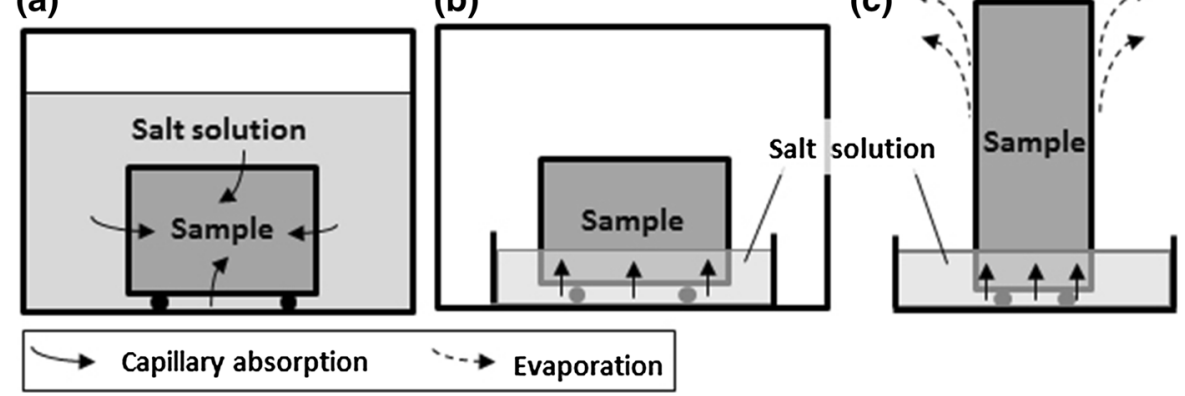

In repeated total or partial immersion tests, salt can either be introduced only in the first cycle (further rewetting is carried out with water), e.g. [16, 67-69], or at every re-wetting, e.g. [4, 18, 70-74].

In wet-dry cycles, the duration of the contamination phase can be set to: (1) a fixed time interval; (2) an interval required for the complete saturation of the specimen; and (3) an interval required for the introduction of a fixed amount of salt. In the last two cases, the interval depends on the absorption behaviour of the test specimen, which has to be assessed in advance. The use of a fixed period of absorption, regardless of the water absorption properties of the materials, can better represent practice, because materials with different properties in similar onsite conditions are likely to absorb different amounts of solution [17]. Common standards and recommendations, e.g. [4-7], prescribe a fixed contamination period. The resulting amount of salt and the depth reached by the salt solution in the material are, therefore, governed by the specimen's absorption properties. In the case of slow absorbing materials and/or of large specimen size, incomplete saturation of the specimen might lead to accumulation of salts in depth and, consequently, to damage in the bulk of the specimen, which is not likely to be representative of the type of decay generally observed in the field (Fig. 5).

The introduction of a fixed amount of salt can be advantageous to study the response of a material to a specific salt amount in relation to its pore volume [75]; this can prove useful, e.g. to establish salt contents below which a surface treatment can be safely applied [58, 76-79]. By adjusting the concentration of the solution to the porosity of the material, and defining the amount of solution as that sufficient for the wetting front to reach the evaporation surface during imbibition by capillarity, the amount of salt in the specimen

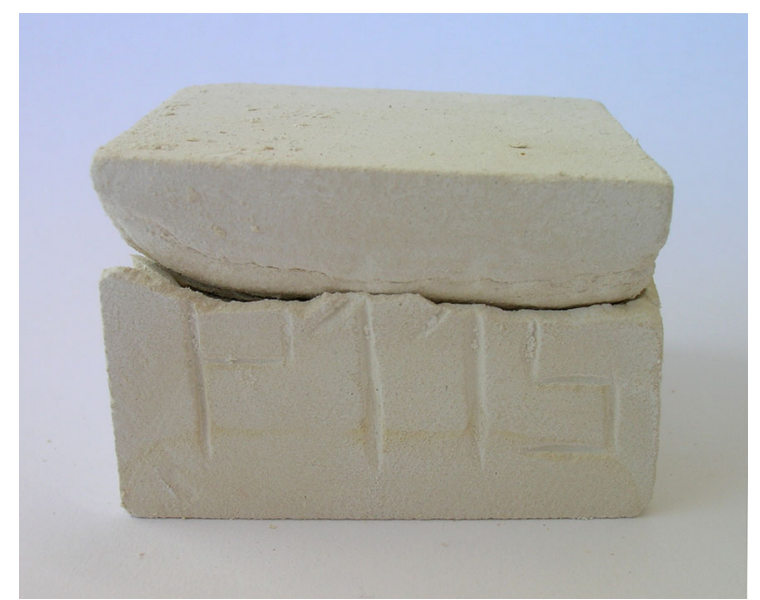

Fig. 5 Limestone specimen after incomplete saturation by partial immersion in a solution of sodium sulphate. Salt has accumulated at depth and led to spalling of a thick layer; this kind of damage is generally not observed in this stone on-site (Nunes C 2008, Methods for the artificial ageing of stone by salt crystallization for use in investigation of stone conservation treatments. M.Sc. dissertation, Instituto Superior Tecnico da Universitade Tecnica de Lisboa, unpublished)

can be easily controlled. This procedure can favour the development of deterioration at the surface (more representative of the situation in practice). However, introducing a given amount of salt can be virtually impossible in some cases, e.g. restoration plasters with water repellent additives. In the European project COMPASS (EU project Compatibility of plasters and renders with salt loaded substrates in historic buildings, EVK4-CT-2001-00047) several procedures were developed to overcome the aforementioned disadvantages. To assess the performance of plasters applied on a substrate, a fixed amount of solution, sufficient to just saturate the substrate, was introduced $[15,17,80]$. In this case the amount of salt and its distribution in the 
plaster layer will depend on the moisture transport properties of the substrate/plaster combination.

\subsection{Properties of the salt solution}

Another important variable in salt contamination procedures is the concentration of the salt solution. The use of highly concentrated or saturated solutions of $\mathrm{Na}_{2} \mathrm{SO}_{4}$ [4, 81-83], and $\mathrm{NaCl}[68,84,85]$ is common in salt crystallisation tests. The same solution concentration is often used for different salt types [6], regardless of their different solubility. As pointed out by Goudie [86], a procedure comprising the continuous or repeated immersion of specimens in saturated salt solutions may simulate the effect of inundation in saline pan environments, but this is a marginal occurrence in practice.

The concentration of the salt solution affects the location of salt accumulation and crystallization and thus damage type and severity. Given the same amount of salt in a specimen, damage is more likely to develop if salt accumulates in a thin layer of material rather than if it is homogeneously distributed in the specimen, because pores become more completely filled, which leads to the development of a higher crystallization pressure [87]. One of the drawbacks of using very high salt concentrations is that the solution viscosity increases, favouring deeper crystallization of the salt in the material [88]. As explained by Ruiz-Agudo et al. [42], the physical properties of the salt solution, i.e. density, surface tension and, in particular, viscosity, have a critical effect on the dynamics of solution flow and evaporation, and therefore, on where and in which pores crystallization occurs, thus determining the damage type and severity. Higher salt concentrations can also favour pore clogging, depending on the type of salt, specimen pore structure [89] and drying conditions [90]. Pore clogging can subsequently reduce the drying rate and favour subflorescences (i.e. crystallization beneath the surface) [60]. Besides, a high salt solution concentration slows down the evaporation rate because the difference in vapour pressure between the material and the environment is reduced [17].

Little attention has been paid to reporting the details about the solution preparation procedure, e.g. density, freshly prepared or aged solution [91]. This aspect can be particularly relevant when using (nearly) saturated solutions. The re-utilization of salt solution may also be an issue, particularly in the case of materials that contain a significant amount of exchangeable ions resulting in change in the actual composition of the salt solution [92]. EN 12370 prescribes the use of a fresh solution for each cycle but some researchers opt to change the solution only every 5 cycles [93]. For salts with solubility highly dependent on temperature, such as sodium sulphate, it is also important to control the temperature of both the solution and the specimen [94].

\subsection{Dissolution/crystallization cycles}

Deliquescence/dissolution/crystallization events are required for damage to develop. Only in a few cases, and especially when using sodium sulphate, damage has been observed after one single crystallization cycle [95-97]; most often, repeated cycles are needed for damage to occur. The results from extensive $\mathrm{NaCl}$ crystallization tests suggest that wetting and drying of the salt loaded specimens can be more relevant for the development of damage than the total amount of salt in the specimens [98]. Similarly, Balboni et al. [44], who studied the damage mechanisms of magnesium sulphate salts in limestone, showed that specimens can also undergo significant deformations at low salt contents, provided they are subjected to several drying-rewetting cycles. These observations are possibly related to salt accumulation in a thin layer of the material, as a result of the repeated wet-dry cycles.

After the first salt contamination phase, dissolution/ re-crystallization cycles can be achieved by re-wetting the specimens with a salt solution or with pure water (liquid or vapour). Re-wetting can take place either from the same surface as in the initial contamination with salt solution (most usual), or from the evaporation surface, opposite to the contamination surface, e.g. $[60,62,99,100]$. A risk related to re-wetting from the top might be the transport of the salt back into the core of the specimen $[99,101]$.

Re-wetting with salt solution is often proposed to speed up the development of damage [17]; this can be effective and realistic, provided that the concentration of the solution is not too high. Conversely, repeated immersion in highly concentrated solutions is expected to: (1) favour pore clogging (e.g. [60]), (2) slow down the drying thus limiting the number of cycles which can be carried out in a given period of time, and (3) hinder salt transport and accumulation 
close to the evaporation surface, possibly leading to cracking and/or bursting in the bulk of the specimen, a type of damage that is not representative of the field situation.

Producing salt dissolution/crystallization cycles in specimens by rewetting with water, in liquid $[6,7]$ or vapour form, can be very effective, while still keeping the salt content within realistic values. Several studies have been carried out in an effort to keep the salt amount at a realistic level and increase the number of dissolution/re-crystallisation cycles by re-wetting with water [50, 88, 98, 102, 103]. Indeed, for salts with multiple anhydrous and hydrated forms with differing solubility (e.g. $\mathrm{Na}_{2} \mathrm{SO}_{4}$ ), wet-dry cycles with liquid water can be very damaging [97, 103]. Damage in this case is believed to be caused by the dissolution of the anhydrous phase (thenardite) followed by the rapid recrystallization of the hydrated phase (mirabilite) [35, 104]. Recently, the possible role of heptahydrate in the damage induced by sodium sulphate has been investigated [105].

Even if damage in specimens contaminated with sodium sulfate can occur through RH cycles alone [106], re-wetting of thenardite with water vapour has been reported to be less damaging than re-wetting with liquid water [37, 97]. In contrast, in the case of sodium chloride, wet-dry cycles obtained by varying the RH of the air around the equilibrium $\mathrm{RH}$ of the salt can produce several crystallization-dissolution cycles in a short period of time and lead to damage, provided that the salts have accumulated near the surface of the specimen and are, hence, responsive to $\mathrm{RH}$ changes [50]. This behaviour can be attributed to the fast hygroscopic uptake of the salt at high RH and to the growth of pure high-quality large crystals from a highly supersaturated solution [107]. In the case of $\mathrm{Na}_{2} \mathrm{SO}_{4}$, damage is less likely to occur in deliquescence-crystallization cycles due to the lower hygroscopicity of this salt and because the growth of isolated hydrated crystals is slow and their life time is short [37].

Continuous partial immersion tests, i.e. simultaneous absorption and drying (wick-effect), are used to simulate the condition in which materials are permanently exposed to rising damp. In this case, no dissolution/re-crystallization cycles of the salt are simulated and damage is caused by the accumulation and crystallization of salts at the drying front. The results of this procedure seem to be highly dependent on the type of salt used and on the environmental conditions. Benavente et al. [93] compared the standard test EN 12370 [4] (wet-dry cycles by total immersion) with the continuous partial immersion of stone in a $\mathrm{Na}_{2} \mathrm{SO}_{4}$ solution with cycles of temperature and $\mathrm{RH}$ (implying thenardite-mirabilite conversion). They observed significant differences in the extent and type of damage between the two test procedures. The continuous partial immersion test gave a distribution and type of damage more similar to that observed in the field than cycles of total immersion. The authors concluded that continuous partial immersion tests were probably a better way to simulate damage resulting from rising damp. Besides, they underlined that this procedure can be easily automated. However, other authors consider that continuous partial immersion might lead to unrealistic conditions: the existence of a permanently saturated surface on which salts crystallize in forms rarely or never seen in buildings, namely large near-equilibrium crystal shapes forming transparent crusts or cauliflower-like agglomerates [17]. This might help explain why the continuous partial immersion test is generally ineffective for those salts, such as $\mathrm{NaCl}$, which tend to effloresce. Moreover, depending on the concentration of the salt solution, an unrealistically high salt content might be reached in the specimen. Using $\mathrm{NaCl}$, Wijffels and Lubelli [15] observed that wetdry cycles with a fixed amount of $\mathrm{NaCl}(1.5 \mathrm{wt} \%)$ introduced by partial immersion in specimens composed of a brick substrate and a salt resistant plaster promoted higher salt accumulation close to the plaster surface (thus increasing the risk of salt damage) than continuous immersion in a $\mathrm{NaCl}$ solution $(10 \mathrm{wt} \%)$. The authors concluded that a procedure allowing as many as possible repeated wet-dry cycles should, therefore, be preferred for this type of salt and substrates.

\section{Drying conditions}

The drying and cooling conditions used in salt crystallization tests have a major influence on the nature, location and rate of salt crystallization, and thus the type of damage induced. Goncalves and Brito [96] provide a summary of the key theoretical stages of drying involved in porous building 
materials. Stage 1 occurs when moisture contents are high and the evaporation front is at the surface (causing a constant drying rate and efflorescence). Stage 2 occurs when moisture contents are lower, and the evaporation front is located within the porous material (declining drying rate and subflorescence result during this stage). However, in practice a transitional phase can also occur, and the presence of salts can complicate any simple drying curves. Pel et al. [108] studied the drying of fired-clay brick specimens contaminated with $\mathrm{NaCl}$ solution in an NMR set-up. They reported that the salt laden specimens showed no receding drying front throughout the duration of the drying experiment (14 days) which was attributed to both the low drying rate conditions used and the wetting properties of the $\mathrm{NaCl}$ solution. Goncalves et al. [26] pointed out that when soluble salts are present, the drying kinetics is not only slower but also more irregular, and drying curves show higher dispersion than for pure water. The authors believe this occurs because salts amplify the dispersion effect that material heterogeneity has on the drying kinetics.

Factors affecting drying rates are temperature, air movement and relative humidity within the experimental set-up. As the complete drying of specimens may require a very long time, particularly when they are salt-contaminated, drying is often accelerated by the use of high temperatures, low $\mathrm{RH}$ and high air speed. The way that high temperatures are obtained can also influence the results. Gomez Heras and Fort [109] investigated whether heating by radiation and convection caused different effects. They found that radiation favoured subflorescence more than convective heating despite identical temperature cycling regimes. When drying occurs in an oven, low reproducibility between different laboratories has been reported [9] which suggests that, as well as temperature, other conditions (e.g. RH and air flow) should also be specified to improve the reproducibility of the test.

Crystallization experiments using full immersion techniques are very common in the literature (e.g. $[4,12,110])$. In these experiments, a short period of immersion in saline solution (often $2 \mathrm{~h}$ ) is followed by an extended period of drying (usually 16-20 h), which in turn is usually followed by a short period of cooling (2-8 h). In most cases, the three stages together add up to $24 \mathrm{~h}$, and this diurnal cycle is repeated several times. Drying temperatures between 60 and $105^{\circ} \mathrm{C}$ are generally used, with cooling under room conditions, despite it being known that temperatures higher than $50-60{ }^{\circ} \mathrm{C}$ can cause microfissures in some stone types (see e.g. [111]). West [9] suggests that the EN12370 [4] procedure might be improved by lowering the drying temperature to $65^{\circ} \mathrm{C}$, as done in the Australian standard AS/NZS 4456:2003 ("Masonry units, segmental pavers and flags-Methods of test") [112].

Angeli et al. [88] studied the effect of different drying and cooling conditions $\left(5^{\circ} \mathrm{C}\right.$, room temperature, and $50{ }^{\circ} \mathrm{C}$ ) on the severity and type of decay of sedimentary stone types contaminated with different concentrations of sodium sulphate solution. They report that higher damage developed at low cooling temperatures and attributed this result to the lower solubility of sodium sulphate at low temperatures, which allows fast supersaturation and thus very fast decay.

Some papers report on complex experiments, such as those carried out by $\mathrm{Yu}$ and Oguchi and Menendez and David who used different temperature and $\mathrm{RH}$ conditions, in order to investigate the aggressiveness of different forms of $\mathrm{Na}_{2} \mathrm{SO}_{4}$ [113] and $\mathrm{CaSO}_{4}$ [114] on the weathering. In both studies, the key role played by drying and cooling conditions on salt damage was confirmed.

Full immersion experiments can also involve more complex drying regimes when they aim to predict the behaviour of different materials under specific field conditions. Geomorphological researchers in particular utilise this approach. Smith et al. [115] provide an example of an experimental study designed to evaluate the importance of stress histories to the behaviour of rocks on desert surfaces. After immersion in $\mathrm{NaCl}$ for $48 \mathrm{~h}$ groups of pristine and pre-stressed limestone and sandstone blocks were air dried for $96 \mathrm{~h}$ at $20{ }^{\circ} \mathrm{C}$, and then exposed in an environmental cabinet to cycles of convective temperature with bursts of radiative heating to simulate warming by solar radiation; significant damage was registered. Other experiments interrupt the drying stage to spray deionized water onto the samples to simulate fog (e.g. [41]), or use extreme temperature and humidity cycling to simulate diurnal cycles of solar heating and dew deposition, e.g. [106]. Arizzi et al. [62] used purpose-designed drying conditions, with temperature and RH cycles and fog 
events (spraying water on the evaporation surface), to study the performance of different mortar mixes.

In partial immersion experiments, samples are contaminated with salts initially through the base of the sample, then dried and re-wetted with deionized water or salt solution, either from the top of the specimen, i.e. evaporation surface, (simulating rain or fog) or from its bottom (simulating rising damp) (see Sect. 4.3). Godts et al. [60] contaminated limestone with $\mathrm{MgSO}_{4}, \mathrm{Na}_{2} \mathrm{SO}_{4}$, and a mixture of the two, then dried them at either $25{ }^{\circ} \mathrm{C}$ and $35 \% \mathrm{RH}$ or $25^{\circ} \mathrm{C}$ and $70 \% \mathrm{RH}$ for 14 days, then applied more water to the top and dried them for a further 14 days. The authors report that the use of low $\mathrm{RH}$ favours pore clogging and the formation of a salt crust which consequently delays drying.

Lubelli et al. [98] used partial immersion methods to contaminate plasters with $\mathrm{NaCl}$ and then dried them under four different scenarios of temperature and $\mathrm{RH}$. The specimens were re-wetted through the side opposite to the evaporation surface when $80 \%$ of the initially applied water had evaporated. The results showed that temperature and air flow have a very important effect on the drying rate and that repeated wet-dry cycles favour migration of the salts towards the evaporation surface. The same author [50] proposes the use of temperature and $\mathrm{RH}$ cycles (between $60{ }^{\circ} \mathrm{C} / 0 \% \mathrm{RH}$ and $20{ }^{\circ} \mathrm{C} / 95 \%$ ) during drying to speed up the drying process and, at the same time, increase the number of dissolution/crystallization cycles. In this way, damage can be significantly accelerated in $\mathrm{NaCl}$ contaminated specimens.

In studies involving the evaluation of mortar performance in composite samples, a possible role of the wetting cycles in the curing of the mortars was highlighted (e.g. [47, 54]), which makes the interpretation of the salt effect more complex.

In experiments involving the continuous partial immersion of specimens in salt solution, different ranges of drying conditions are used. For example, Benavente et al. [93] used partial immersion of limestone and sandstone specimens in $\mathrm{Na}_{2} \mathrm{SO}_{4}$ and a two stage drying: $12 \mathrm{~h}$ at $40{ }^{\circ} \mathrm{C}$ and $80 \% \mathrm{RH}$, followed by $12 \mathrm{~h}$ at $10^{\circ} \mathrm{C}$ and $70 \% \mathrm{RH}$. Goudie [52] used cycles of $7 \mathrm{~h}$ at $55^{\circ} \mathrm{C}$ and $17 \mathrm{~h}$ at $22{ }^{\circ} \mathrm{C}$ (with no control of RH) in his study of the 'wick effect' of a range of salt solutions on sandstone.

The selection of the drying conditions is sometimes determined by the goals of the experiment. Cardell et al. [116] used temperature and humidity regimes to reproduce natural conditions in Granada, southern Spain, while Rodriguez-Navarro and Doehne [46] used low (35\%) and medium-high (60\%) RH conditions at $20{ }^{\circ} \mathrm{C}$ to compare the effects of mirabilite and thenardite, crystallizing at $\mathrm{RH}>50 \%$ and at $\mathrm{RH}<$ $50 \%$, respectively.

Another relevant parameter is the use of free or constrained drying conditions. Under free conditions, evaporation can occur from all the faces of the specimen, whilst under constrained conditions 4 or 5 faces are sealed to prevent evaporation. Sealing can be obtained either by applying a tape, film or adhesive, or by applying an impermeable coating (usually an epoxy resin) or placing blocks within polystyrene 'moulds' or other devices, which may also exert a mechanical constraint or thermal insulation on blocks.

\section{Assessment method}

Many, more or less complex, methods and techniques are used for the assessment of the results of salt crystallization tests. The occurrence of damage is mostly assessed by comparison between the situation before and after the test. The methods used depend on the aims of the study and, sometimes, also on the available laboratory equipment.

\subsection{Visual and photographic observations and weight change}

Standards and recommendations suggest simple assessment methods, which can be carried out at any laboratory, without the need for specific facilities. RILEM Tests No. V.1a, b (total immersion) [5] and EN 12370 [4] prescribe reporting the mass change or the number of cycles needed to completely destroy the samples (in case complete disintegration occurs in less than 15 cycles). A photographic record of the specimen condition is required only at the beginning and at the end of the test. RILEM Test No. V.2 (partial immersion) [5] requires a "visual (photographic) evaluation" only, and recording the mass change is stated to be "less suitable" in this case. Similarly, RILEM MS-A.1 [6] suggests recording the visual changes (by photographs and description) and the number of units that have failed after each cycle. The criterion of "failure" must be specified in every 
individual case. Thus, a comparison between different materials and units is difficult and might be biased by subjective considerations.

All in all, as "visual (photographic) evaluation" is highly affected by subjectivity, mass change is the only measurable and quantitative property proposed in the standard tests. However, recording the mass change has important limitations: mass change is a combination of mass increase due to repeated salt contamination and mass loss due to damage. Besides, when damage occurs as cracking of the specimen without any material loss, it becomes impossible to use mass change as the only criterion.

In most scientific studies of salt decay, the development of damage is usually monitored by weighing the specimen after each drying cycle in combination with visual and photographic record. Several authors further developed the mass change criterion to extract relevant and objective information on the weathering and its evolution. Some authors collected the debris after dissolution of the salt to monitor more precisely the loss of material (e.g. [39, 50]). As salt can cement loose particles, some authors suggested brushing the specimen after the wetting phase to facilitate removal of debris [50] or immersing it in water at the end of the test [46]. Goudie et al. [38] classified the material loss according to the size of the fragments in order to gain quantitative information on the type of damage (e.g. splitting or granular disintegration). The same author some years later [52] used four different parameters to express the nature of stone breakdown: (a) weight of the largest remaining particle, expressed as a percentage of the initial weight; (b) combined weight of detached particles above $2 \mathrm{~g}$ as a percentage of the initial weight; (c) number of detached particles above $2 \mathrm{~g}$ and (d) weight percentage of particles less than $1 \mathrm{~mm}$ in diameter. On particles weighing less than $2 \mathrm{~g}$, a granulometry study was performed. A combination of these parameters was used by the same author to define an Index of Disintegration. Later on, other authors also tried to define indices to facilitate the comparison between specimens: e.g. Angeli et al. [117] established the Alteration Index, i.e. the number of the cycle during which one can see the first sign of damage, and the Alteration Velocity, i.e. the slope of the plot representing the weight loss in percentage as a function of the cycle number, allowing assessment of the dynamics of the weathering process.
In some studies, photographic recording has been replaced by time-lapse videos, which allows a better representation of the evolution of damage over time [46]. In some others, a more standardized description of the damage has been attempted in order to make visual assessment more objective (e.g. [25, 69]).

\subsection{Other methods}

\subsubsection{Non-destructive techniques}

In most studies, visual/photographic inspection and mass change measurement are complemented with more or less complex investigation techniques. Some of these are non-destructive and allow monitoring of damage during the test, while some others are destructive and are, therefore, generally carried out only at the end of the test.

Some non-destructive techniques focus on the observation of changes occurring on the surface of the material. Vazquez et al. [118] measured color changes in limestone samples after salt crystallization tests, but did not observe any significant changes. As salt damage generally affects the surface of the material, laser [119, 120] and optical profilometers (Fig. 6) [96] have been used to characterize the surface

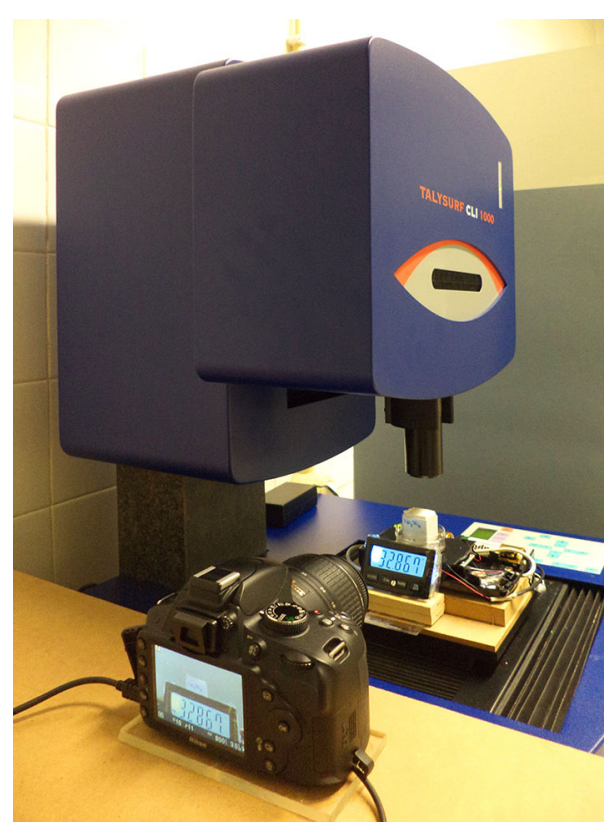

Fig. 6 Optical profilometer [using a white light (CLA) gauge] for monitoring of surface changes 
decay and monitor its evolution. Other authors use a combination of digital camera, reflectography and fiber optic microscope images [121]. Recently, more advanced techniques such as X-ray CT [23, 122], and neutron tomography [123] have been successfully applied to study the development of damage in the bulk of the material. These 3D imaging techniques allow not only qualitative monitoring of the weathering process, but also quantitative determination of the location of the accumulation of salt and the opening of fractures [90, 122-125] (Fig. 7). Synchrotron radiation energy-dispersive X-ray diffraction has also been used to monitor salt distribution in limestone samples [126].

Another non-destructive technique which has found application in the monitoring of the decay is acoustic emission and measurement of ultrasonic P-wave velocity. Menéndez and David [114] continuously recorded the generated acoustic emission to detect salt weathering by $\mathrm{CaSO}_{4}$ precipitation (Fig. 8), a method which had been already suggested by Grossi et al. [127]. Akin and Ozsan [24] found decay function models following an exponential law between P-wave velocity and Unconfined Compressive Strength (UCS) as a function of the number of crystallization cycles performed on travertine samples. Also, Aly et al. [128] used ultrasonic P-wave velocity to characterize limestone samples after partial immersion tests. Moreover, they applied non-destructive measurements of surface hardness (Leeb number, rebound hardness) and found good correlation between UCS and rebound hardness, whereas the correlation between P-wave velocity and UCS was weak. The authors attributed this to the fact that the P-wave velocity was first increased (compared to the untreated samples) by the filling of stone pores with salts; later it was reduced due to the formation of cracks.

\subsubsection{Destructive techniques}

Among the destructive techniques for the study of the effect of salt crystallization on a material, mercury intrusion porosimetry (MIP) is one of the most commonly used. The measurement of changes in porosity and pore size distribution by MIP is considered to provide information on the location of salt deposition (if carried out after the test and prior to desalination) and on the damage (if carried out after the test on desalinated samples) (e.g. [42, 46, 47, 62, 98, 110, 129, 130]. The limitations of MIP are well known (e.g. [131]): the instrument measures the pore throat and not the actual pore size, thus possibly leading to misinterpretation of data; assumptions are made on contact angle values and pore shape which may strongly affect the results. Despite these limitations, the ease of data collection
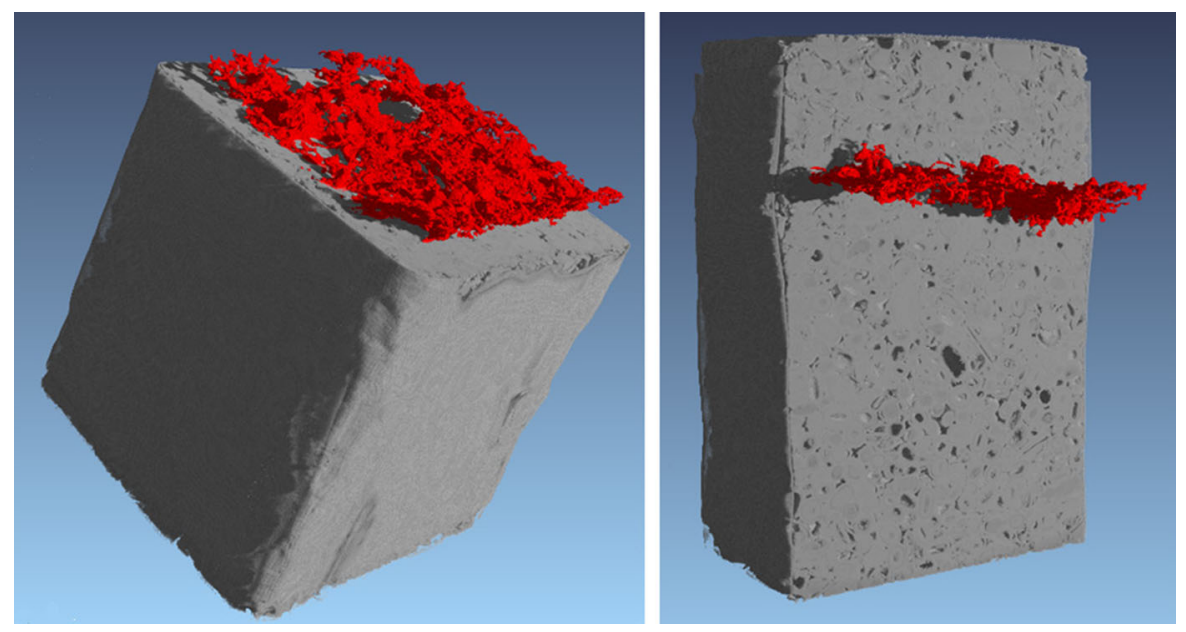

Fig. 7 3D reconstruction of X-ray tomographic dataset of a Savonnières limestone sample after 4 wetting-drying cycles with a 1.4 molal $\mathrm{Na}_{2} \mathrm{SO}_{4}$-solution. The sample was sealed on its lateral sides and the upper volume was treated with a hydrophobic agent prior to the imbibition-drying cycles in order to induce a precipitation front below the top surface. The crack volume is indicated in red and visualized by partly cutting the stone volume ([125], reproduced with permission of the author). (Color figure online) 

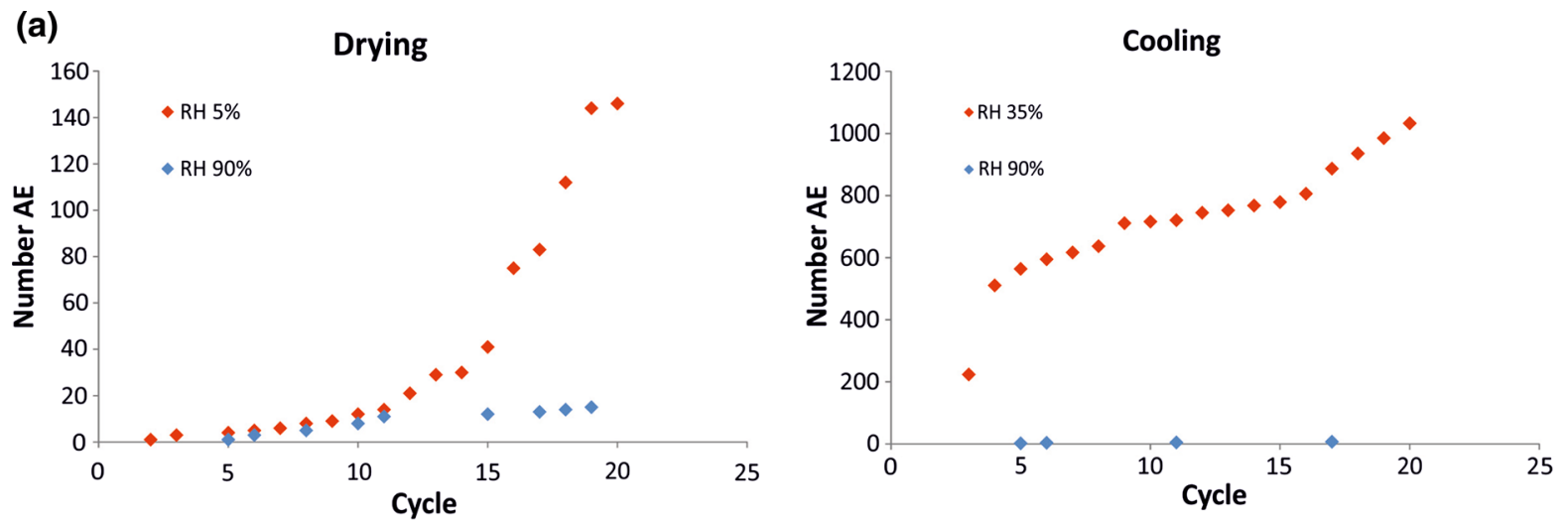

(b)

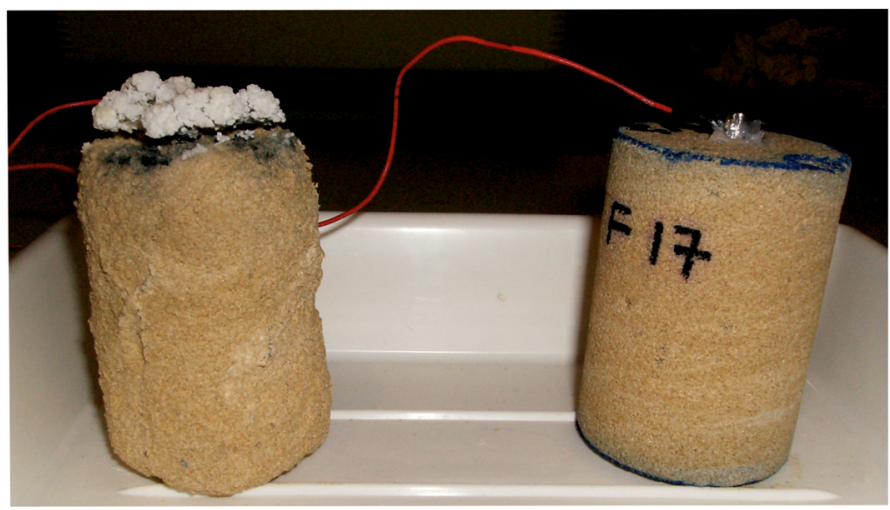

Fig. 8 Use of acoustic emission techniques on limestone specimens during a salt crystallization test with sodium sulfate. a Cumulative number of events recorded by acoustic emission

and elaboration has contributed to the diffusion of the use of this method.

In some studies, the difference in mechanical (flexural, tensile and/or compressive) strength of the material before and after the crystallization test is used as a measure of decay [30], sometimes in combination with NDT methods. For example, Akin and Ozsan [24] determined the UCS of travertine stones with different porosity after an increasing number of crystallization cycles and showed that repeated magnesium and sodium sulphate crystallization significantly reduce the compressive strength. Similarly, Ludovico-Marques [132] determined the evolution of mechanical properties of sandstone blocks during a crystallization test. Aly et al. [128] characterized the UCS of partially immersed stone samples after different times of treatment.

One of the limitations of mechanical strength measurements is that the combined effect of salt technique during drying $\left(20 \mathrm{~h}\right.$ at $\left.50{ }^{\circ} \mathrm{C}\right)$ and cooling $(2 \mathrm{~h}$ at $20{ }^{\circ} \mathrm{C}$ ). b Samples after 16 cycles: drying and cooling at 5\% RH (left) and 90\% RH (right)

accumulation in pores (increasing the material strength [133]), moisture, and damage (decreasing the material strength), complicate the interpretation of the results.

Microscopy techniques, including optical [134, 135] and (environmental) electron scanning microscopy, sometimes equipped with energy dispersive X-ray spectrometry (e.g. [46, 55, 101, 135, 136]), are also often used to study damage due to salt crystallization. Generally, microscopic observations are carried out at the end of the test, without prior desalination of the sample, to assess the presence and type of damage and relate this to the salt distribution in the specimen (e.g. [115] and the location of salt in pores [50, 133]).

Sometimes, destructive methods are used to assess quantitatively the distribution of salt in the specimens during and/or at the end of the test. The technique usually encompasses the slicing or grinding of the 
specimen along its length or powder-drilling of the samples at different depths. The salt content in the samples can then be measured by the hygroscopic moisture content method [137, 138], or by ion chromatography (IC) $[17,50,51,98]$ or electrical conductivity [103]. Modestou et al. [139] used the drilling resistance measurement system (DRMS) and the scratch tool to monitor the salt crystallization front in salt weathered limestone, both in the laboratory and in situ. Arizzi et al. [62] analyzed by IC the amount of soluble cations present in mortar specimens at the end of a crystallization test with sodium sulfate.

The precision of the salt distribution analysis is determined by the thickness of each sampling interval. Given the importance of salt distribution in the development of damage, its assessment is of crucial importance for designing a salt crystallization test, namely regarding the contamination procedure and the drying regime. Besides, salt distribution can be used to determine the risk of future damage in those specimens showing no decay at the end of the test: a high accumulation of salt directly beneath the surface implies a higher risk than a homogenous distribution of salt throughout the depth of the specimen. A similar approach was followed by other researchers for assessing the risk of damage due to accumulation of salts behind the consolidated layers in bricks [65] and limestone [66], such accumulation possibly leading to spalling of the treated layer.

\section{Discussion and conclusions}

This review highlights that a wide range of accelerated salt weathering procedures has been proposed in the literature, due to both the limitations of current standard methods and the different goals of the studies.

Focussing on the assessment of material durability and repair material compatibility, the first key step in the establishment of an accelerated test is the choice of the type of specimen, which should be representative of the situation in practice. The review highlights for many situations the importance of testing combinations of different materials (assembled specimens), and of taking into account material peculiarities, such as bedding planes in natural stones. Small size specimens should be preferred to speed up the wetting and drying steps. However, the size of the specimen should be large enough to be representative of the material properties and of the simulated damage process. The shape of the specimen often depends on the damage assessment method. Generally, cylinders have the advantage of limiting the corner effects present in prismatic specimens. Although standards and recommendations suggest a high number of replicates (6 in [4], 10 in [6]), 3 (or even fewer) replicates are generally used in laboratory tests; requiring a much larger number of replicates seems therefore impractical. A compromise should nevertheless be found between practical issues and reliability of the results.

The assessment of the reviewed references shows that single salts (mainly $\mathrm{Na}_{2} \mathrm{SO}_{4}$ and $\mathrm{NaCl}$ ) are most commonly used in crystallization tests. Salt mixtures are rarely adopted, probably because of the complexity in the interpretation of the results and because mixtures were often found to be less damaging than single salts. Salts with multiple hydrates with different solubility (such as sodium and magnesium sulphate) are the most damaging ones in accelerated weathering tests. However, this conclusion might be partially biased by the test procedures generally used in literature (immersion-drying cycles promoting the rapid re-crystallization of the hydrated forms after dissolution of the anhydrous one), as the kind of cycle is decisive for the measured aggressiveness of a salt. In fact, salts like sodium chloride have also proven to be very damaging, provided that effective weathering conditions are selected (frequent dissolution/crystallization cycles of the salt due to $\mathrm{RH}$ changes). These observations suggest that the most effective procedure depends on the type of salt used.

Often, a very high salt content in the specimens is used in salt crystallization tests, but this literature review suggests that this might be counter-productive in some cases, leading to unrealistic damage type without necessarily speeding up the occurrence of damage.

The large variety of contamination and drying procedures reported in the literature, and the fact that they are rarely compared with each other, makes it difficult to draw conclusions on their relative effectiveness and reliability. However, it is clear that contamination and drying procedures can affect the durability ranking of the tested materials. In fact, the contamination procedure (amount, concentration and supply of salt solution) and the drying conditions affect the salt accumulation in the material. The degree 
of pore filling and the crystallization pressure, together with the (micro)mechanical properties of the material, determine the onset of the damage [140].Extreme drying conditions are very often used in laboratory weathering tests, because of the need to accelerate the damage process; however these conditions often lead to damage types (e.g. cracks in the bulk of the sample, complete disintegration) that are far from representative of reality. As the decay type depends on the location of salt crystallization, it is important in a crystallization test that salt accumulation occurs where this is to be expected in the field, i.e. near the surface of the material, for a test to be reliable and significant. This can be favoured by the use of unsaturated solutions, initial saturation of the specimen by capillarity and not too extreme drying regimes.

This review shows that several techniques can be used to assess and monitor the decay, qualitatively and quantitatively, destructively and non-destructively, with different levels of complexity, precision and cost. Generally, visual observation and mass change are used for monitoring the decay, sometimes complemented by additional techniques. In the definition of a standard crystallization test and prescription of assessment methods, preference should be given to economically affordable and preferably non-destructive monitoring methods and techniques, which are easily accessible for most laboratories and do not require very specialized expertise.

Existing standards and recommendations provide no criteria for the classification of the durability of the tested material. In publications, conclusions are drawn only by comparison between the different tested materials (relative ranking). Providing criteria for such a classification would confer an additional value to the to-be-developed salt crystallization procedure.

In conclusion, this paper provides an overview of existing literature on accelerated salt crystallization tests, underlines open questions and suggests directions for the to-be developed salt crystallization procedure. These ideas, together with those resulting from research on modelling of salt transport and crystallization pressure [87], will contribute to the definition of improved procedures for the assessment of the durability of materials with respect to salt crystallization.

\section{Compliance with ethical standards}

Conflict of interest The authors declare that they have no conflict of interest.

Open Access This article is distributed under the terms of the Creative Commons Attribution 4.0 International License (http:// creativecommons.org/licenses/by/4.0/), which permits unrestricted use, distribution, and reproduction in any medium, provided you give appropriate credit to the original author(s) and the source, provide a link to the Creative Commons license, and indicate if changes were made.

\section{References}

1. Goudie AS, Viles HA (1997) Salt weathering hazards. Wiley, Chichester

2. Charola AE (2000) Salts in the deterioration of porous materials: an overview. J Am Inst Conserv 39:327-343

3. Doehne E (2002) Salt weathering: a selective review, salt weathering: a selective review. Geol Soc Spec Pub 205(1):51-64

4. CEN (1999) EN 12370 Natural stone test methods. Determination of resistance to salt crystallization

5. RILEM (1980) Recommended tests to measure the deterioration of stone and to assess the effectiveness of treatment methods, Test V.1a-crystallization test by total immersion (for untreated stone); Test V.1b—crystallization test by total immersion (for treated stone); Test V.2crystallization test by partial immersion. Mater Struct 13(75): 175-253

6. RILEM TC 127-MS (1998) MS-A.1-determination of the resistance of wallettes against sulphates and chlorides. Mater Struct 31:2-9

7. RILEM TC 127-MS (1998) MS-A.2-uni-directional salt crystallization test for masonry units. Mater Struct 31:10-11

8. WTA Merkblatt 2-9-04/D (2005) Sanierputzsysteme/ Renovation mortar systems. WTA Publications, Stuttgart

9. West D (2000) Brard's test into the 21st century: sodium sulphate soundness testing of dimension stone. In: McNally GH, Franklin BJ (eds) Sandstone city: Sydney's dimension stone and other sandstone geomaterials. Proceedings of a symposium held on 7th July 2000, during the 15th Australian geological convention at the University of Technology, Sydney. Geological Society of Australia, Environmental, Engineering and Hydrology Specialist Group, Monograph 5, pp 138-148

10. Doehne E, Selwitz C, Carson D (2002) The damage mechanism of sodium sulphate in porous stone. In: Proceedings of the SALTeXPERT meeting, pp 27-146

11. Lubelli B, Van Hees RPJ, Nijland TG (2014) Salt crystallization damage: how realistic are existing ageing tests? In: De Clercq $\mathrm{H}$ (ed) Proceedings of the international conference on salt weathering of buildings and stone sculptures (SWBSS 2014), Aedificatio Publishers, Brussels, pp 259-273 
12. Beck K, Al-Mukhtar M (2010) Evaluation of the compatibility of building limestones from salt crystallization experiments. Geol Soc Lond Spec Publ 333(1):111-118. https://doi.org/10.1144/sp333.11

13. Van Hees RPJ, Brocken HJP (2001) Interaction of the SBW treatment with $\mathrm{Na}_{2} \mathrm{SO}_{4}, \mathrm{NaCl}$ and $\mathrm{NaNO}_{3}$. In: De Witte E (ed) Salt compatibility of surface treatment (SCOST), final report, EU Contract No. ENV4-CT980710, pp 109-119

14. Van Hees RPJ, Brocken HJP (2004) Damage development to treated brick masonry in a long-term salt crystallisation test. Constr Build Mater 18(5):331-338. https://doi.org/10. 1016/j.conbuildmat.2004.02.006

15. Wijffels T, Lubelli B (2006) Development of a new accelerated salt crystallization test. Heron 51(1):63-79

16. Velosa AL, Veiga MR (2006) Development of artificial ageing tests for renders: application to conservation mortars. In: Thompson G (ed) Proceedings of the 7th international masonry conference, British Masonry Society, London

17. Gonçalves TD (2007) Salt crystallisation in plastered or rendered walls. Ph.D. dissertation, Instituto Superior Técnico da Universidade Técnica de Lisboa

18. Fragata A, Veiga MR, Velosa A (2016) Substitution ventilated render systems for historic masonry: salt crystallization tests evaluation. Constr Build Mater 102(1):592-600. https://doi.org/10.1016/j.conbuildmat. 2015.10.130

19. Franzoni E, Gentilini C, Santandrea M, Zanotto S, Carloni C (2017) Durability of steel FRCM-masonry joints: effect of water and salt crystallization. Mater Struct. https://doi. org/10.1617/s11527-017-1070-2

20. Groot CJWP (1993) Effect of water on mortar-brick bond. Ph.D. dissertation, Delft University of Technology

21. Wijffels TJ, Van Hees RPJ (2000) The influence of the loss of water of the fresh mortar to the substrate on the hygric characteristics of so-called restoration plaster. In: Verhoef L, Wittman F (eds) Proceedings of the international workshop on urban heritage and building maintenance VII, Aedificatio Publishers, Freiburg, pp 49-54

22. Smith BJ, McGreevy JP (1983) A simulation study of salt weathering in hot deserts. Geogr Ann Ser A 65(1-2):127-133. https://doi.org/10.1080/04353676. 1983.11880079

23. Cnudde V, De Boever W, Dewanckele J, De Kock T, Boone M, Boone MN et al (2013) Multi-disciplinary characterization and monitoring of sandstone (Kandla Grey) under different external conditions. Q J Eng Geol Hydrogeol 46(1):95-106. https://doi.org/10.1144/ qjegh2012-005

24. Akin M, Özsan A (2011) Evaluation of the long-term durability of yellow travertine using accelerated weathering tests. Bull Eng Geol Environ 70(1):101-114. https:// doi.org/10.1007/s10064-010-0287-x

25. Kyriakou L, Theodoridou M, Ioannou I (2017) Assessment of the durability of lime renders with Phase Change Material (PCM) additives against salt crystallization. In: Laue S (ed) Proceedings of the fourth international conference on salt weathering of buildings and stone sculptures (SWBSS 2017), University of Applied Sciences, Potsdam, pp 81-89
26. Diaz Gonçalves T, Brito V, Musacchi J, Pel L, Saidov T, Delgado Rodrigues J, Costa D, Mimoso JM (2014) Drying of porous building materials possibly contaminated with soluble salts: summary and findings of the DRYMASS research project. In: De Clercq $\mathrm{H}$ (ed) Proceedings of the international conference on salt weathering of buildings and stone sculptures (SWBSS 2014), Aedificatio Publishers, Brussels, pp 1-15

27. Janvier-Badosa S, Beck K, Brunetaud X, Guirimand-Dufour A, Al-Mukhtar M (2015) Gypsum and spalling decay mechanism of tuffeau limestone. Environ Earth Sci 74(3):2209-2221. https://doi.org/10.1007/s12665-0154212-2

28. Angeli M, Bigas J-P, Benavente D, Menéndez B, Hébert R, David C (2007) Salt crystallization in pores: quantification and estimation of damage. Environ Geol 52(2):205-213. https://doi.org/10.1007/s00254-006-0474-z

29. Dewanckele J, Boone MA, De Kock T, De Boever W, Brabant L, Boone MN et al (2013) Holistic approach of pre-existing flaws on the decay of two limestones. Sci Total Environ 447:403-414. https://doi.org/10.1016/j. scitotenv.2012.12.094

30. Nunes C, Slížková Z, Křivanková D (2013) Lime-based mortars with linseed oil: sodium chloride resistance assessment and characterization of the degraded material. Period Mineral 82(3):411-427. https://doi.org/10.2451/ 2013pm0024

31. Bachmat Y, Bear J (1987) On the concept and size of a representative elementary volume (rev). In: Bear J, Corapcioglu MY (eds) Advances in transport phenomena in porous media. NATO ASI series (Series E: applied sciences), vol 128. Springer, Dordrecht

32. Al-Raoush R, Papadopoulos A (2010) Representative elementary volume analysis of porous media using X-ray computed tomography. Powder Technol 200(1-2):69-77

33. ASTM Subcommittee D18.17 (2013) ASTM 5240 standard test method for evaluation of durability of rock for erosion control using sodium sulfate or magnesium sulfate

34. Steiger M, Asmussen S (2008) Crystallization of sodium sulfate phases in porous materials: the phase diagram $\mathrm{Na}_{2} \mathrm{SO}_{4}-\mathrm{H}_{2} \mathrm{O}$ and the generation of stress. Geochim Cosmochim Acta 72(17):4291-4306. https://doi.org/10.1016/ j.gca.2008.05.053

35. Rodriguez-Navarro C, Doehne E, Sebastian E (2000) How does sodium sulfate crystallize? Implications for the decay and testing of building materials. Cem Concr Res 30(10):1527-1534. https://doi.org/10.1016/s0008-8846 (00)00381-1

36. Flatt RJ (2002) Salt damage in porous materials: how high supersaturations are generated. J Cryst Growth 242: 435-454. https://doi.org/10.1016/s0022-0248(02)01429-x

37. Desarnaud J, Bertrand F, Shahidzadeh-Bonn N (2013) Impact of the kinetics of salt crystallization on stone damage during rewetting/drying and humidity cycling. J Appl Mech 80(2):020911. https://doi.org/10.1115/1. 4007924

38. Goudie A, Cooke R, Evans I (1970) Experimental investigation of rock weathering by salts. Area 2(4):42-48

39. Kwaad FJPM (1970) Experiments on the granular disintegration of granite by salt action. Fysisch Geografisch 
Bodemkundig Laboratorium From Field to Laboratory 16:67-80

40. Cooke RU (1979) Laboratory simulation of salt weathering processes in arid environments. Earth Surf Process 4(4):347-359. https://doi.org/10.1002/esp.3290040405

41. Wells T, Binning P, Willgoose G, Hancock G (2006) Laboratory simulation of the salt weathering of schist: 1 . Weathering of schist blocks in a seasonally wet tropical environment. Earth Surf Proc Land 31(3):339-354. https:// doi.org/10.1002/esp. 1248

42. Ruiz-Agudo E, Mees F, Jacobs P, Rodriguez-Navarro C (2007) The role of saline solution properties on porous limestone salt weathering by magnesium and sodium sulfates. Environ Geol 52(2):269-281. https://doi.org/10. 1007/s00254-006-0476-X

43. Ioannou I, Fournari R, Petrou MF (2013) Testing the soundness of aggregates using different methodologies. Constr Build Mater 40:604-610

44. Balboni E, Espinosa-Marzal RM, Doehne E, Scherer GW (2010) Can drying and re-wetting of magnesium sulfate salts lead to damage of stone? Environ Earth Sci 63(7-8):1463-1473. https://doi.org/10.1007/s12665-0100774-1

45. Espinosa-Marzal RM, Scherer GW (2011) Mechanisms of damage by salt. Geol Soc Lond Spec Publ 331(1):61-77. https://doi.org/10.1144/sp331.5

46. Rodriguez-Navarro C, Doehne E (1999) Salt weathering: influence of evaporation rate, supersaturation and crystallization pattern. Earth Surf Proc Land 24(3):191-209

47. Gentilini C, Franzoni E, Bandini S, Nobile L (2012) Effect of salt crystallisation on the shear behaviour of masonry walls: an experimental study. Constr Build Mater 37:181-189. https://doi.org/10.1016/j.conbuildmat.2012. 07.086

48. Stefanidou M, Papayanni I (1999) Resistance of repair mortars of historic structures to wetting-drying salt cycles. In: Arun G (ed) Proceedings of the international symposium studies on historical heritage (SHH07), Y1ldız Technical University, Istanbul, pp 347-354

49. Steiger M (2005) Crystal growth in porous materials-I: the crystallization pressure of large crystals. J Cryst Growth 282(3-4):455-469. https://doi.org/10.1016/j. jcrysgro.2005.05.007

50. Lubelli B (2006) Sodium chloride damage to porous building materials. Ph.D. dissertation, Delft University of Technology

51. Gonçalves TD, Pel L, Rodrigues JD (2009) Influence of paints on drying and salt distribution processes in porous building materials. Constr Build Mater 23(5):1751-1759. https://doi.org/10.1016/j.conbuildmat.2008.08.006

52. Goudie AS (1986) Laboratory simulation of "the wick effect" in salt weathering of rock. Earth Surf Proc Land 11(3):275-285. https://doi.org/10.1002/esp.3290110305

53. De Freece SN, Weber J, Charola AE (2005) Hygric behaviour of two of the most deteriorating salts: sodium sulphate and sodium carbonate. Restor Build Monum 11(2):79-86. https://doi.org/10.1515/rbm-2005-5938

54. López-Arce P, Tagnit-Hammou M, Menéndez B, Mertz J-D, Kaci A (2016) Durability of stone-repair mortars used in historic buildings from Paris. Mater Struct
49(12):5097-5115. https://doi.org/10.1617/s11527-0160846-0

55. Tingstad A (2008) Simulation of salt weathering in a closely replicated coastal environment. Geogr Ann Ser A 90(2):165-171. https://doi.org/10.1111/j.1468-0459.2008. 00166.x

56. Williams RGB, Robinson DA (1998) Weathering of sandstone by alunogen and alum salts. Q J Eng Geol 31:369-373

57. Robinson DA, Williams RBG (2000) Experimental weathering of sandstone by combinations of salts. Earth Surf Proc Land 25:1309-1315

58. De Clercq H (2008)The effect of other salts on the crystallization damage to stone caused by sodium sulfate. In: Proceedings of the SWBSS2008 conference, Copenhangen, 2008, pp 307-315

59. De Clercq H, Jovanovic M, Linnow K, Steiger M (2013) Performance of limestones laden with mixed salt solutions of $\mathrm{Na}_{2} \mathrm{SO}_{4}-\mathrm{NaNO}_{3}$ and $\mathrm{Na}_{2} \mathrm{SO}_{4}-\mathrm{K}_{2} \mathrm{SO}_{4}$. Environ Earth Sci 69:1751-1761. https://doi.org/10.1007/s12665-0122017-0

60. Godts S, Hendrickx R, De Clercq H (2014) The crystallization behavior of sodium magnesium sulfate in limestone. In: De Clercq H (ed) Proceedings of the third international conference on salt weathering of buildings and stone sculptures (SWBSS 2014), Aedificatio Publishers, Brussels, pp 167-182

61. Menéndez B, Petráňová V (2016) Effect of mixed vs single brine composition on salt weathering in porous carbonate building stones for different environmental conditions. Eng Geol 210:124-139. https://doi.org/10.1016/j.enggeo. 2016.06.011

62. Arizzi A, Viles H, Cultrone G (2012) Experimental testing of the durability of lime-based mortars used for rendering historic buildings. Constr Build Mater 28(1):807-818. https://doi.org/10.1016/j.conbuildmat.2011.10.059

63. Benavente D, Martínez-Martínez J, Cueto N, García-delCura MA (2007) Salt weathering in dual-porosity building dolostones. Eng Geol 94(3-4):215-226. https://doi.org/10. 1016/j.enggeo.2007.08.003

64. Alves C, Figueiredo C, Maurício A (2017) A critical discussion of salt weathering laboratory tests for assessment of petrological features susceptibility. Proc Earth Planet Sci 17:324-327. https://doi.org/10.1016/j.proeps.2016.12. 082

65. Graziani G, Sassoni E, Franzoni E (2016) Experimental study on the salt weathering resistance of fired clay bricks consolidated by ethyl silicate. Mater Struct 49(7): 2525-2533. https://doi.org/10.1617/s11527-015-0665-8

66. Sassoni E, Graziani G, Franzoni E (2016) An innovative phosphate-based consolidant for limestone. Part 2: durability in comparison with ethyl silicate. Constr Build Mater 102:931-942. https://doi.org/10.1016/j.conbuildmat.2015. 10.202

67. Goudie AS, Parker AG (1998) Experimental simulation of rapid rock block disintegration by sodium chloride in a foggy coastal desert. J Arid Environ 40(4):347-355. https://doi.org/10.1006/jare.1998.0465

68. Henriques FMA, Charola AE (2000) Development of lime mortars with improved resistance to sodium chloride crystallization. In: Fassina V (ed) Proceedings of the 9th 
international conference on deterioration and conservation of stone, vol 2. Elsevier, Venice, pp 335-342

69. Lubelli B, Nijland TG, Van Hees RPJ, Hacquebord A (2010) Effect of mixed in crystallization inhibitor on resistance of lime-cement mortar against $\mathrm{NaCl}$ crystallization. Constr Build Mater 24(12):2466-2472. https:// doi.org/10.1016/j.conbuildmat.2010.06.010

70. Goudie AS (1999) Experimental salt weathering of limestones in relation to rock properties. Earth Surf Proc Land 24:175-724

71. Van Tri T, Beck K, Al-Mukhtar M (2006) Accelerated weathering tests on two highly porous limestones. Environ Geol 52(2):283-292. https://doi.org/10.1007/s00254-0060532-6

72. Ioannou I, Hoff WD (2008) Water repellent influence on salt crystallisation in masonry. Proc Inst Civil Eng Constr Mater 161(1):17-23. https://doi.org/10.1680/coma.2008. 161.1.17

73. Alves C, Figueiredo C, Maurício A, Braga MAS, AiresBarros L (2011) Limestones under salt decay tests: assessment of pore network-dependent durability predictors. Environ Earth Sci 63(7-8):1511-1527. https://doi. org/10.1007/s12665-011-0915-1

74. Franzoni E, Gentilini C, Graziani G, Bandini S (2014) Towards the assessment of the shear behaviour of masonry in on-site conditions: a study on dry and salt/water conditioned brick masonry triplets. Constr Build Mater 65:405-416. https://doi.org/10.1016/j.conbuildmat.2014. 05.002

75. Van Hees RPJ, Brocken H (2003) The salt crystallisation method. In: De Witte E (ed) Salt compatibility of surface treatment (SCOST), final report, EU Contract No. ENV4CT98-0710, institution? city?, pp 35-37

76. Miquel A, Bromblet P, Vergès-Belmin V (2003) Compatibility of SBW treated substrates with $\mathrm{Na}_{2} \mathrm{SO}_{4}$. In: De Witte E (ed) Salt compatibility of surface treatment (SCOST), final report, EU Contract No. ENV4-CT980710, institution? city? pp 73-95

77. De Clerq H, De Witte E (2003) Interaction of the type of treatment with different types of salt. In: De Witte E (ed) Salt compatibility of surface treatment (SCOST), final report, EU Contract No. ENV4-CT98-0710, institution? city? pp 142-144

78. De Clercq H (2005) Performance of single materials treated with a water repellent and contaminated with a salt mix. In: Silfwerbrand J (ed) Proceedings of the 4th international conference on water repellent treatment of building materials (Hydrophobe IV), Aedificatio Publishers, Brussels, Aedificatio Publishers, Freiburg, pp 171-184

79. De Clercq H (2008) Performance of limestone contaminated with binary mixtures of sodium sulphate and treated with a water repellent. In: De Clercq H (ed) Proceedings of the 5th international conference on water repellent treatment of building materials (Hydrophobe V), Aedificatio Publishers, Brussels, pp 107-116

80. Vergès-Belmin V, Wijfels T, Gonçalves TD, Nasraoui M (2005) The COMPASS salt crystallization test as a way to figure out how salts migrate and accumulate in renovation plasters. In: Van Hees RPJ (ed) Compatibility of plasters and renders with salt loaded substrates in historic buildings, final report, EU Contract No. EVK4-CT-20010047-DGXII, institution? city? pp 157-168

81. López-Doncel R, Wedekind W, Leiser T, Molina-Maldonado S, Velasco-Sánchez A, Dohrmann R, Kral A, Wittenborn A, Aguillón-Robles A, Siegesmund S (2016) Salt bursting tests on volcanic tuff rocks from Mexico. Environ Earth Sci. https://doi.org/10.1007/s12665-0154770-3

82. Cultrone G, Sebastián E, Huertas MO (2007) Durability of masonry systems: a laboratory study. Constr Build Mater 21(1):40-51. https://doi.org/10.1016/j.conbuildmat.2005. 07.008

83. Sassoni E, Franzoni E, Graziani G, Sagripanti F (2014) Limestone resistance to sodium sulfate degradation after consolidation by hydroxyapatite and TEOS. In: De Clercq $\mathrm{H}$ (ed) Proceedings of the international conference on salt weathering of buildings and stone sculptures (SWBSS 2014), Aedificatio Publishers, Brussels, pp 335-345

84. Rivas T, Alvarez E, Mosquera MJ, Alejano L, Taboada J (2010) Crystallization modifiers applied in granite desalination: the role of the stone pore structure. Constr Build Mater 24(5):766-776. https://doi.org/10.1016/j. conbuildmat.2009.10.031

85. Aly N, Gomez-Heras M, Hamed A, Alvarez de Buergo M, Soliman F (2014) Porosity changes after different temperature regimes for a salt weathering simulation test on Mokkattam limestone (Egypt). In: De Clercq H (ed) Proceedings of the international conference on salt weathering of buildings and stone sculptures (SWBSS 2014), Aedificatio Publishers, Brussels, pp 247-257

86. Goudie AS (1993) Salt weathering simulation using a single-immersion technique. Earth Surf Proc Land 18(4):369-376. https://doi.org/10.1002/esp.3290180406

87. Flatt R et al (2017) Predicting salt damage in practice: a theoretical insight into laboratory tests. RILEM Tech Lett 2:108-118

88. Angeli M, Hébert R, Menéndez B, David C, Bigas J-P (2010) Influence of temperature and salt concentration on the salt weathering of a sedimentary stone with sodium sulphate. Eng Geol 115(3-4):193-199. https://doi.org/10. 1016/j.enggeo.2009.06.001

89. Espinosa-Marzal RM, Scherer GW (2012) Impact of inpore salt crystallization on transport properties. Environ Earth Sci 69(8):2657-2669. https://doi.org/10.1007/ s12665-012-2087-z

90. Derluyn H, Boone MA, Boone MN, De Kock T, Desarnaud J, Peetermans S, Molari L, De Miranda S, Shahidzadeh N, Cnudde V (2015) Salt crystallization dynamics in building rocks: a 4D study using laboratory X-ray micro-CT. In: Long B (ed) Proceedings of the 2nd international conference on tomography of materials and structures (ICTMS 2015), Québec, pp 565-568

91. Shahidzadeh-Bonn N, Rafaï S, Bonn D, Wegdam G (2008) Salt crystallization during evaporation: impact of interfacial properties. Langmuir 24(16):8599-8605. https://doi. org/10.1021/la8005629

92. Schäfer M, Steiger M (2002) A rapid method for the determination of cation exchange capacities of sandstones: preliminary data. Geol Soc Lond Spec Publ 205(1):431-439. https://doi.org/10.1144/gsl.sp.2002.205. 01.31 
93. Benavente D, García del Cura M, Bernabéu A, Ordóñez S (2001) Quantification of salt weathering in porous stones using an experimental continuous partial immersion method. Eng Geol 59(3-4):313-325. https://doi.org/10. 1016/s0013-7952(01)00020-5

94. Tsui N, Flatt RJ, Scherer GW (2003) Crystallization damage by sodium sulfate. J Cult Herit 4(2):109-115. https://doi.org/10.1016/s1296-2074(03)00022-0

95. Delgado Rodrigues J, Ferreira Pinto A, Nunes C (2007) Preparation of aged samples for testing stone treatments. In: Proceedings of the 23th international convention Scienza e Beni Culturale-Il Consolidamento degli Apparati Architettonici e Decorativi, Arcadia Ricerche, Marghera Venezia, pp 597-605

96. Diaz Gonçalves T, Brito V (2014) Alteration kinetics of natural stones due to sodium sulfate crystallization: can reality match experimental simulations? Environ Earth Sci 72(6):1789-1799. https://doi.org/10.1007/s12665-0143085-0

97. Stahlbuhk A, Nissen J, Linnow K, Steiger M (2014) Influence of the salt concentration on the damage potential of mirabilite and thenardite. In: De Clercq H (ed) Proceedings of the international conference on salt weathering of buildings and stone sculptures (SWBSS 2014), Aedificatio Publishers, Brussels, pp 35-48

98. Lubelli B, van Hees RPJ, Groot CJWP (2006) The effect of environmental conditions on sodium chloride damage. Stud Conserv 51(1):41-56. https://doi.org/10.1179/sic. 2006.51.1.41

99. Lindström N, Heitmann N, Linnow K, Steiger M (2015) Crystallization behavior of $\mathrm{NaNO}_{3}-\mathrm{Na}_{2} \mathrm{SO}_{4}$ salt mixtures in sandstone and comparison to single salt behavior. Appl Geochem 63:116-132. https://doi.org/10.1016/j. apgeochem.2015.07.007

100. Cnudde V, Cnudde JP, Dupuis C, Jacobs PJS (2004) X-ray micro-CT used for the localization of water repellents and consolidants inside natural building stones. Mater Charact 53:259-271

101. Desarnaud J, Derluyn H, Molari L, De Miranda S, Cnudde V, Shahidzadeh N (2015) Drying of salt contaminated porous media: effect of primary and secondary nucleation. J Appl Phys 118(11):114901. https://doi.org/10.1063/1. 4930292

102. Lubelli B, Van Hees RPJ, Huinink HP, Groot CJWP (2006) Irreversible dilation of $\mathrm{NaCl}$ contaminated limecement mortar due to crystallization cycles. Cem Concr Res 36(4):678-687. https://doi.org/10.1016/j.cemconres. 2005.10.008

103. MacWilliam K (2017) Aging tests to assess the durability of building materials to salt crystallization-towards a more realistic and effective use of sodium sulfate. M.Sc. dissertation, Czech Technical University in Prague

104. Shahidzadeh-Bonn N, Desarnaud J, Bertrand F, Chateau X, Bonn D (2010) Damage in porous media due to salt crystallization. Phys Rev E 81(6):066110. https://doi.org/ 10.1103/physreve.81.066110

105. Brito V, Saidov TA, Gonçalves TD, Pel L (2014) Delamination of Ançã limestone due to sodium sulfate under different environmental conditions as studied by nuclear magnetic resonance. J Build Phys 38(5):465-482. https://doi.org/10.1177/1744259114543981
106. Goudie AS, Viles HA (1995) The nature and pattern of debris liberation by salt weathering: a laboratory study. Earth Surf Proc Land 20(5):437-449. https://doi.org/10. 1002/esp.3290200505

107. Desarnaud J, Bertrand F, Shahidzadeh-Bonn N (2011) Dynamics of salt crystallization. In: Ioannou I, Theodoridou M (eds) Proceedings of the international conference on salt weathering of buildings and stone sculptures (SWBSS 2011), University of Cyprus, Limassol, pp 23-29

108. Pel L, Huinink H, Kopinga K (2003) Salt transport and crystallization in porous building materials. Magn Reson Imaging 21(3-4):317-320. https://doi.org/10.1016/s0730$725 \times(03) 00161-9$

109. Gomez-Heras M, Fort R (2007) Patterns of halite $(\mathrm{NaCl})$ crystallisation in building stone conditioned by laboratory heating regimes. Environ Geol 52(2):239-247. https://doi. org/10.1007/s00254-006-0538-0

110. Angeli M, Benavente D, Bigas J-P, Menéndez B, Hébert R, David C (2007) Modification of the porous network by salt crystallization in experimentally weathered sedimentary stones. Mater Struct 41(6):1091-1108. https://doi.org/10. $1617 / \mathrm{s} 11527-007-9308-\mathrm{Z}$

111. Siegesmund S, Ruedrich J, Weiss T (2004) Marble deterioration. In: Prikryl R (ed) Dimension stone. Taylor \& Francis, London, pp 211-217. ISBN 90-5809-675-0

112. Australian standard AS/NZS 4456:2003 (2003) Masonry units, segmental pavers and flags-methods of test

113. Yu S, Oguchi CT (2013) Is sheer thenardite attack impotent compared with cyclic conversion of thenardite-mirabilite mechanism in laboratory simulation tests? Eng Geol 152(1):148-154. https://doi.org/10.1016/j.enggeo. 2012.10.009

114. Menéndez B, David C (2013) The influence of environmental conditions on weathering of porous rocks by gypsum: a non-destructive study using acoustic emissions. Environ Earth Sci 68(6):1691-1706. https://doi.org/10. 1007/s12665-012-1861-2

115. Smith BJ, Warke PA, McGreevy JP, Kane HL (2005) Saltweathering simulations under hot desert conditions: agents of enlightenment or perpetuators of preconceptions? Geomorphology 67(1-2):211-227. https://doi.org/10. 1016/j.geomorph.2004.03.015

116. Cardell C, Benavente D, Rodríguez-Gordillo J (2008) Weathering of limestone building material by mixed sulphate solutions. Characterization of stone microstructure, reaction products and decay forms. Mater Charact 59(10):1371-1385

117. Angeli M, Bigas J-P, Menéndez B, Hébert R, David C (2006) Influence of capillary properties and evaporation on salt weathering of sedimentary rocks. In: Fort R, Alvarez de Buergo M, Gomez-Heras M, Vazquez-Calvo C (eds) Proceedings of the international conference on heritage, weathering and conservation, Taylor \& Francis, Leiden, pp 253-259

118. Vázquez P, Menéndez B, Denecker MFC, ThomachotSchneider C (2015) Comparison between petrophysical properties, durability and use of two limestones of the Paris region. Geol Soc Lond Spec Publ. https://doi.org/10.1144/ SP416.15

119. Binda L, Baronio G, Ferrieri ED (1997) Durability of brick masonry surface treatments to salt crystallization. In: 
Proceedings of the 11th international brick/block masonry conference, Tongji University, Shanghai, pp 732-741

120. Gomez-Heras M, Smith BJ, Viles HA, Meneely J, McCabe S (2008) High definition laser scanning for the evaluation of salt decay laboratory simulations of building limestone. In Proceedings of the salt weathering on buildings and stone sculptures (SWBSS 2008), Technical University of Denmark, Copenhagen, pp 149-158

121. Kapsalas P, Maravelaki-Kalaitzaki P, Zervakis M, Delegou ET, Moropoulou A (2007) Optical inspection for quantification of decay on stone surfaces. NDT and E Int 40(1):2-11. https://doi.org/10.1016/j.ndteint.2006.07.012

122. Dewanckele J, De Kock T, Boone MA, Cnudde V, Brabant L, Boone MN, Fronteau G, Van Hoorebeke L, Jacobs P (2012) 4D imaging and quantification of pore structure modifications inside natural building stones by means of high resolution X-ray CT. Sci Total Environ 416:436-448. https://doi.org/10.1016/j.scitotenv.2011.11.018

123. Derluyn H, Griffa M, Mannes D, Jerjen I, Dewanckele J, Vontobel P, Sheppard A, Derome D, Cnudde V, Lehmann E, Carmeliet J (2013) Characterizing saline uptake and salt distributions in porous limestone with neutron radiography and X-ray micro-tomography. J Build Phys 36(4):353-374. https://doi.org/10.1177/1744259112473947

124. Derluyn H (2012) Salt transport and crystallization in porous limestone: neutron-X-ray imaging and poromechanical modeling, Dissertation ETH No. 20673, ETH Zurich, Switzerland. https://doi.org/10.3929/ethz-a007578301

125. Derluyn H, Dewanckele J, Boone MN, Cnudde V, Derome D, Carmeliet J (2014) Crystallization of hydrated and anhydrous salts in porous limestone resolved by synchrotron X-ray microtomography. Nucl Instrum Methods Phys Res, Sect B 324:102-112. https://doi.org/10.1016/j. nimb.2013.08.065

126. Ioannou I, Hall C, Hoff WD, Pugsley VA, Jacques SDM (2005) Synchrotron radiation energy-dispersive X-ray diffraction analysis of salt distribution in Lépine limestone. Analyst 130(7):1006-1008. https://doi.org/10.1039/ b504274g

127. Grossi CM, Esbert RM, Suárez del Río LM, Montoto M, Laurenzi-Tabasso M (1997) Acoustic emission monitoring to study sodium sulphate crystallization in monumental porous carbonate stones. Stud Conserv 2(2):115-125. https://doi.org/10.2307/1506623

128. Aly N, Hamed A, Gomez-Heras M, Benavente D, Alvarez de Buergo M (2016) The effect of salt crystallisation on the mechanical properties of limestone: statistical correlations between non-destructive and destructive techniques. In: Hughes J, Howind T (eds) Science and art: a future for stone-proceedings of the 13th international congress on the deterioration and conservation of stone, vol 1, University of the West of Scotland, Paisley, pp 225-231
129. Prikryl R, Lokajicek T, Svobodova J, Weishauptova Z (2003) Experimental weathering of marlstone from Predni Kopanina (Czech Republic)—historical building stone of Prague. Build Environ 38(9-10):1163-1171. https://doi. org/10.1016/S0360-1323(03)00073-8

130. Molina E, Cultrone G, Sebastián E, Alonso FJ (2013) Evaluation of stone durability using a combination of ultrasound, mechanical and accelerated aging tests. J Geophys Eng 10(3):035003. https://doi.org/10.1088/ 1742-2132/10/3/035003

131. Van Brakel J, Modrý S, Svatá M (1981) Mercury porosimetry: state of the art. Powder Technol 29(1):1-12. https://doi.org/10.1016/0032-5910(81)85001-2

132. Ludovico-Marques M, Chastre C (2012) Effect of salt crystallization ageing on the compressive behavior of sandstone blocks in historical buildings. Eng Fail Anal 26:247-257. https://doi.org/10.1016/j.engfailanal.2012. 08.001

133. Stefanidou MA (2009) A contribution to salt crystallization into the structure of traditional repair mortars through capillarity. In: Fernandes I (ed) Proceeding of the 11th euroseminar on microscopy applied to building materials (EMABM), Elsevier, Amsterdam, pp 106-112

134. Bai Y, Thompson G, Martinez-Ramirez S, Brueggerhoff S (2003) Mineralogical study of salt crusts formed on historic building stones. Sci Total Environ 302(1-3):247-251. https://doi.org/10.1016/s0048-9697(02)00339-x

135. Cardell C, Rivas T, Mosquera JJ, Birginie JM, Moropoulou A, Prieto B, Silva B, Van Grieken R (2003) Patterns of damage in igneous and sedimentary rocks under conditions simulating sea-salt weathering. Earth Surf Proc Land 28:1-14

136. Benavente D, García del Cura MA, García-Guinea J, Sánchez-Moral S, Ordóñez S (2004) Role of pore structure in salt crystallisation in unsaturated porous stone. J Crystal Growth 260(3-4):532-544. https://doi.org/10.1016/j. jcrysgro.2003.09.004

137. Lubelli B, van Hees RPJ, Brocken HJP (2004) Experimental research on hygroscopic behaviour of porous specimens contaminated with salts. Constr Build Mater 18(5):339-348. https://doi.org/10.1016/j.conbuildmat. 2004.02 .007

138. Diaz Gonçalves T, Delgado Rodrigues J (2006) Evaluating the salt content of salt-contaminated samples on the basis of their hygroscopic behavior. Part I: fundamentals, scope and accuracy of the method. J Cult Herit 7(2):79-84. https://doi.org/10.1016/j.culher.2006.02.009

139. Modestou S, Theodoridou M, Ioannou I (2015) Microdestructive mapping of the salt crystallization front in limestone. Eng Geol 193:337-347. https://doi.org/10. 1016/j.enggeo.2015.05.008

140. Flatt RJ, Caruso F, Sanchez AMA, Scherer GW (2014) Chemomechanics of salt damage in stone. Nat Commun 5(4823):1-5. https://doi.org/10.1038/ncomms5823 